\title{
UNDERSTANDING GOVERNMENT AFFIRMATIVE ACTION AND METRO BROADCASTING, INC. V. FCC
}

\author{
SAMUEL L. STARKS
}

[F]reedom is not enough. You do not wipe away the scars of centuries by saying: Now you are free to go where you want, and do as you desire, and choose the leaders you please. You do not take a person who, for years has been hobbled by chains and liberate him, bring him up to the starting line of a race and then say, "you are free to compete with all others," and still justly beheve that you have been completely fair. We seek not just freedom but opportumity. We seek not just legal equity but human ability, not just equality as a right and a theory but equality as a fact and equality as a result.

-President Lyndon B. Johnson ${ }^{1}$

\section{INTRODUCTION}

President Lyndon Johnson uttered these hopeful words to an audience of black college graduates at Howard University's 1965 commencenient. His statement reflects a conviction that America nuust do niore tlian pay hip service to equal opportunity and economic and political en1powerment for black Americans. ${ }^{2}$ It also reflects Johnson's behief in affirmative action as an effective antidiscrimination policy-one that he thought was a necessary, practical, and niorally justifiable nieans of ensuring that black Americans are afforded "equality as a fact and as a result," rather than niere "equality as a right and a theory."3

Nearly three decades have passed since Johnson's inspirational speech, the passage of the landmark Civil Rights Act of 1964,4 and a host of otler civil rights and social-welfare legislation; yet, our nation is still

1. Lyndon B. Johnson, Commencement Address at Howard University: "To Fulfill These Rights," in 1965 PuB. PaPers 636 (1966).

2. See id. ("It is not enough just to open the gates of opportumity. All of our citizens must have the ability to walk through those gates. This is the next and the more profound stage of the battle for civil rights."). Johnson, a Southern Democrat, is noted for his administration's support of social-welfare and civil rights legislation. See 6 THE NEw ENCYCLOPEDIA BRITANNICA 593 (15th ed. 1989).

3. See Johnson, supra note 1. Johnson's words embraced the view expressed by Justice Harry Blackmun in Regents of the Umiversity of California v. Bakke, 438 U.S. 265 (1978): "In order to get beyond racism, we must first take account of race. . . A And im order to treat some persons equally, we must treat them differently." Id. at 407 (Blackmun, J., concurring).

4. Civil Rights Act of 1964, Pub. L. No. 88-352, 78 Stat. 241 (1964). This watershed Act was designed to end discrimination in the Umited States based on race, sex, religion, or national origin. 
very far from being the land of equal opportunity and equality that Jolınson envisioned. There remains significant inequality between blacks and whites in education, ${ }^{5}$ enployment, ${ }^{6}$ housing, ${ }^{7}$ and incorne. ${ }^{8}$ Sorne attribute this inequality to forces that are beyond the control of blacks, such as past and present societal discrimination. The Lawyer's Coinmittee for Civil Rights Under Law, for example, contends that "[r]acial and ethnic

5. Consider the remarks made at the National Urban League's State of Black America 1992 press conference regarding the status of black American education:

Education has been the historic gateway to a better life for all Americans, especially for African Americans. However, as we begin 1992, some 37 years after Brown vs. the Board of Education, most African American children remain in schools that are separate and decidedly unequal. Educational achievement among African Americans continues to lag behind that of all other racial and ethnic groups. Low educational achievement among African Americans has resulted not only froin poverty and prejudice but also from the structured expectation in our schools that American children-African American children will fail.

State of Black America Message by John Jacob of National Urban League, National Press Club, Washington, DC, FED. NEws SERviCE, Jan. 21, 1992, available in LEXIS, Nexis Library, Wires File.

6. Recent data from the Department of Labor Statistics on employment and earnings reveal the unequal status of blacks in the American work force:

[T] he five top-paying occupational categories for males were professional, managerial, sales, technicians, and craft... [T] hese are the occupations in which the proportions of blacks employed were relatively low. Employed black males were only about half as likely as white males to be employed im managerial, sales, or professional occupations, and only about three-quarters as likely to be employed as technicians or craft workers. On the other hand, black males were employed at much higher rates in the five lowest-paying occupational categories [craft and repair; machine and assembly line operators; transportation and materials movers; handlers, cleaners, and helpers; and farming, forestry, and fishimgl.

The situation was similar for fentales, although the degree of inequality was somewhat less. Black females were underrepresented in the four high-paid largely female occupations of sales, professionals, managerial, and administrative support. They were overrepresented in the lower-paid, less prestigious occupations of service workers, operators and household workers.

David H. Swinton, The Economic Status of African Americans: "Permanent" Poverty and Incquality, in National Urban League, The State of Black America 25, 62.63 (1989) [hereinafter STATE OF BLACK AMERICA].

7. According to the National Urban League, "[a]bout a third of all poor African Americans live in substandard housing - about two-and-a-half tines the proportion of poor whites living in such circumstances." John E. Jacob, Black America, 1989: An Overview, in STATE OF BlaCK AMERICA, supra note 6 , at $1,2$.

8. Based on census and Bureau of Labor Statistics data, David Swinton reports that in 1989, black per capita income of $\$ 8,747$ was $41 \%$ less than white per capita inconte of $\$ 14,896$. Swinton, supra note 6 , at 29 . In 1989 , blacks had an imcome deficit equal to $\$ 6,149$ for every black man, woman, and child. In the aggregate, the income of the African-American population was $\$ 186$ billion short of the income required for parity. Id. In 1989, the median meome of black males was $\$ 12,609$, only $60.4 \%$ of the white male median income; the median income of black females was only $80.3 \%$ as much as the income of white females, and the median black family income of $\$ 20,209$ was only $56.2 \%$ of the median white family income. In the same year, there were about 9.3 million black persons living in poverty, or approximately $30 \%$ of the black population. Id. 
discrimination continues to impose significant barriers to the opportunities of minorities throughout our society."9

Although racisn in the United States nay not be as pervasive today as it was during other periods of our nation's history, a recent survey conducted by the National Opinion Research Center reveals that racisn1 is still a prevalent force in our society. This survey found that niany whites still harbor negative, stereotypical images of blacks and other racial ininorities. ${ }^{10}$ For nistance, seventy-eight percent of whites surveyed thought that blacks were nore likely than whites to prefer hiving on welfare and seventy-four percent thought that Hispanics were inore likely than whites to prefer welfare. ${ }^{11}$ Sixty-two percent of whites thought that blacks were less likely than whites to be hard-working and fifty-six percent thought blacks were less intelligent than whites. ${ }^{12}$ Fifty-six percent of whites thought that Hispanics were nore likely than whites to be lazy, fifty percent thought Hispanics were nore likely than whites to be prone to violence, and fifty-five percent thought Hispanics were less likely to be intelhigent. ${ }^{13}$

Regardless of how one feels about affirmative action, its use and justification by the goveriment cannot be addressed or understood outside the context of the evidence of racisn1, discrininiation, and niequality that exists in our society. ${ }^{14}$

Affirmative action is a frequent topic of debate in the United States, yet it is largely inisunderstood by the American public, including niany lawyers, elected officials, acadermicians, and journalists who daily influence policies relating to it. As political scientist Abralıain Davis notes: "The term, affirmative action, has been tossed around carelessly and given a connotation which creates uunecessary misunderstanding, halftruths, hostility, suspicion, antiblack attitudes and divisiveness."15 One need only look to the recent debate over the 1990 and 1991 civil rights

9. Brief of Lawyer's Counmittee for Civil Rights Under Law as Amicus Curiae in support of Respondents at 5, Metro Broadcasting v. FCC, 110 S. Ct. 2997 (1990) (No. 89-453) (citing numerous sources supporting its assertion that discrimination continues to deny equal opportunity to blacks and other ininorities).

10. See Carleton R. Bryant, Recession, Racism, Double Trouble for Black Americans, WaSH. Times, Jan. 9, 1991, at A1; Sam Fulwood I1I, Attitudes on Minorities in Conflict, L.A. Times, Jan. 9, 1991, at A13.

11. Fullwood, supra note 10, at A13.

12. Id.

13. Id.

14. Of course, affirmative action applies not just to black Americans, but also to woinen and other racial minorities. For the purpose of clarity and convenience, however, this Note discusses affirmative action as it relates to and affects black Americans.

15. Abraham L. Davis, Blacks in the Federal Judiciary 44 (1989). 
bills to see the confusion and controversy that often surround the issue of affirmative action. ${ }^{16}$

If properly designed and administered, affirmative action is a justifiable and fair means of combatting past, present, and future discrimination against minorities. ${ }^{17}$ The primary objective of this Note, however, is not to argne the virtues of affirmative action. Rather, it is designed to help the reader better understand affirmative action by examining and clarifying some of the issues that contribute to the confusion and controversy over the policy. ${ }^{18}$ In doing so, this Note will focus on the Supreme Court's most recent affirmative action decision, Metro Broadcasting, Inc. v. FCC. ${ }^{19}$ The Court in Metro Broadcasting considered two inatters consolidated on appeal and by a five to four inajority ${ }^{20}$ upheld the affirmative action measures at issue in those cases.

Each case involved the constitutionality of a congressionally mandated minority ownership policy of the Federal Comınunications Commission (FCC); both policies were designed to reinedy the poor

16. When questioned about his opposition to the 1990 and 1991 civil rights bills, President Bush frequently responded by stating that he was not opposed to a civil rights bill, but would not sign a "quota" bill. Sharon LaFraniere \& Tom Kenworthy, Attomey General Criticizes Revised Civil Rights Bill as 'Hoax,' WASH. Post, May 13, 1991, at A13. The 1990 bill was vetoed by Bush; the veto was upheld when the Senate failed to get the necessary votes to override it. Id. Despite language in the bills that prohibited quotas, the White House, joined by congressional Republicans, argued that the bills "would force einployers to resort to quotas, to hire fewer qualified people and to cut back on their requirements for jobs." Id. According to Democrats, however, the bills were merely desigued to reverse six 1989 Supreme Court rulings that made it difficult for minorities to bring job discrimination suits. Id. Rejecting Bush's claim that the 1990 and 1991 civil rights bills are "quota bills," Democrats argued that Republican opposition to the bills was an attack on affirmative action. Id.

As one political writer observes: "Talking quotas is sure to be alluring when the 1992 presidential campaigu begins. A recession will swell the numbers of ordinary whites fed up with affinnative action. They don't think it works; they don't think it's fair to them-and they don't think saying so makes them racists." Tom Mathews, Quotas, NEwSWEEK, Dec. 31, 1990, at 29. Mathews predicts that by attacking affirmative action, Bush will be able to say to prospective white voters: "If you don't get a job, promotion or a place in the freshmen class, blane the Democrats. They are the ones mugging the middle class and giving the spoils to their minority friends." Id.

17. Although portions of this Note will strongly reflect the author's view of affirmative action, both pro and con views on the issue are presented throughout this Note.

18. Although there is a tremendous anount of hiterature that discusses affirmative action, most (if not all) of this material is written with the assumption that the reader has a clear understanding of what affirmative action is and how it works. This Note attempts to address the issue in a manner that is more descriptive than analytical. It is desigued to help compensate for the highly political and fraginented discussions of affirmative action that exist in the popular press, books, law reviews, and other literature.

19. 110 S. Ct. 2997 (1990). For a detailed discussion of Metro Broadcasting see infra Part III.

20. Justice Brennan delivered the opinion of the Court, in which Justices White, Marshall, Blackmun, and Stevens, joined. Metro Broadcasting, $110 \mathrm{~S}$. Ct. at 3002 . Justice Stevens filed a separate opinion concurring in the judginent. Id. at 3028. Justice O'Connor filed a dissenting opinion, in which Justices Rehnquist, Scalia, and Kennedy joined. Id. Justice Kennedy filed a separate dissenting opinion in which Scalia joined. Id. at 3044. 
representation of minorities ${ }^{21}$ in the broadcasting industry. ${ }^{22}$ This Note focuses on Metro Broadcasting not because the Court upheld the affirmative action measures at issue, but because it provides a comprehensible and contemporary framework for examining the current debate surrounding affirmative action. Metro Broadcasting is a particularly suitable vehicle for examining affirmative action because it concerns race-conscious government affirmative action pohicies that have an enormous impact on the general public. Additionally, the arguments for and agamst affirmative action advanced in Metro Broadcasting expand the range of legal, political, and philosophical views on the subject and demonstrate the nature and extent of disagreenent about affirmative action.

Part I of this Note defines affirmative action and briefly traces the historical origin and meaning of affirmative action in this country. Part II focuses on the legal framework for analyzing affirmative action by discussing the Equal Protection Clause of the Fourteenth Amendinent and important Supreme Court opinions on race-conscious government affirmative action programs. After explaining the intent and operation of the FCC minority ownership policies at issue in Metro Broadcasting, Part III critically exainines the legal reasoning of the majority opinion and concludes that the inajority correctly upheld the FCC policies. Additionally, Part III rejects the dissenters' arguinents that the stigina associated with affirmative action outweighs its benefit to society and that affirmative action is an unjust policy because it benefits and burdens the wrong individuals. Part IV addresses the status quo and likely future of government affirmative action by assessing the current inakeup of the Supreine Court and the current pohtical climate in the Umited States. Part V concludes that one should refrain froin making a judgment about affirmative action without being sure of what it means, how it works, and what constitutional primciples govern its use.

\section{The Origin and Meaning of Affirmative Action}

Lyndon Johnson's efforts to secure equal opporturity for black Americans resulted in the federal government's adoption of affirmative

21. See id. at 3000 . The FCC defined "minority" to include those of "Black, Hispanic Surnanied, American Eskino, Aleut, American Indian and Asiatic American extraction." Id. at 3002 n.1; see also Statenent of Policy on Minority Ownership of Broadcasting Facilities, 68 F.C.C.2d 979, 980 n.8 (1978) (citations omitted).

22. See Metro Broadcasting, 110 S. Ct. at 3003 ("In 1971, minorities owned only 10 of the approximately 7,500 radio stations in the country and none of the more than 1,000 television stations, ... in 1978, minorities owned less than 1 percent of the Nation's radio and television stations, $\ldots$ and in 1986 , they owned just 2.1 percent of the more than 11,000 radio and television stations in the United States."). 
action policies for the first time in 1961.23 As Vice President in John F. Kennedy's admimistration, Johnson was the "chief architect"24 of President Kennedy's Executive Order 10,925,25 popularly known as the "Affirmative Action Order."26 The order had little substantive effect, but symbolically launclied the issue of equal opportunity for blacks and other minorities into public discourse. ${ }^{27}$ Specifically, the order prohibited the federal government and its contractors from discriminating against "any employee or apphicant for employment because of race, creed, color, or national origin." 28 It also mandated that government contractors take "affirmative action to ensure that applicants are einployed, and that einployees are treated during employment, witlout regard to their race, creed, color, or national origin." 29

As President, Johnson signed Executive Order 11,246 in 1965,30 whicli superseded Executive Order 10,925 and put "real muscle" into federally mandated affirmative action practices. ${ }^{31}$ Like its predecessor, this order prohibited the federal government and its hired contractors from discriminating based on "race, creed, color, or national origin," but it went furtlier by declaring that "eacls executive departinent and agency sliall establisli and maintain a positive program of equal einployment opportunity." 32 It is not clear from eitlier order what is meant by the phrase "affirnative action."

In its broadest meaning, the phrase "affirnative action" is now generally understood to refer to the practice of favorably considering an individual's status as a woinan, or as a member of a racial or ethnic

23. Hugh D. Graham, The Civil Rights Era: Origins and Development of NaTIONAL POLICY 33 (1990).

24. Id. at 6.

25. Exec. Order No. 10,925, 3 C.F.R. 448 (1961).

26. GraHAM, supra note 23 , at 33 .

27. See id. at 6. The term "affirmative action" did not originate with either Kennedy's or Johnson's executive orders, but dates back to at least the early 1930s. See id. at 33. Congress included the phrase "affirmative action" in the Wagner Act of 1935, which defined the duties and authority of the National Labor Relations Board (NLRB). The Wagner Act provided that the NLRB could order employers found guilty of employment discrimination "to cease and desist from such unfair labor practice, and to take such affirmative action, including reinstatement of employees with or without back pay, as will effectuate the policies of this Act." National Labor Relations Act, Pub. L. No. 74-198, 449 Stat. 454 (1935).

28. Exec. Order No. 10,925, 3 C.F.R. at 448.

29. Id.

30. See Exec. Order No. 11,246, 3 C.F.R. 339 (1965).

31. Daniel C. Maguire, A New American Justice 29 (1980). For a more detailed discussion of the order, see Note, Executive Order 11,246 and Reverse Discrimination Challenges: Presidential Authority to Require Affirmative Action, 54 N.Y.U. L. REV. 376 (1979).

32. Exec. Order No. 11,246, 3 C.F.R. at 339. As applied to federal government contractors, the langnage from Executive Order 11,246 was taken verbatim from Kennedy's Executive Order 10,925. Graham, supra note 23 , at 188. 
minority group. ${ }^{33}$ Affirmative action is designed to aid those that have suffered historic and widespread mistreatment in the form of both de jure and de facto discrimination. ${ }^{34}$ Affirmative action might also be described as a temporary policy einbraced by government, businesses, and universities as a means of achieving true equal opportunity-what President Johnson described as "equality as a fact and as a result." 35 Affirmative action policies are frequently used in awarding business contracts, in hiring and promotions, and in umversity admissions and granting of scholarships.

Often referred to as "benign discrimination," 36 affirmative action is generally designed with three goals in mind: to eliminate existing discrimination against women, racial, and ethnic minorities; to remedy the lingering effects of past discrimination against these groups; and to prevent future discrimination against these groups. ${ }^{37}$ Affirmative action is

33. As one writer notes: "Listen to the noisy public debate about affirmative action, and you'd think the issue is entirely about hiring preferences for blacks. But the government's employment rules cover 48 million white women, 10 million Hispanics, and 3 million Asians im addition to 13 million blacks-in all 54\% of the labor force." Paula Dwyer, The 'Other Minorities' Demand Their Due, Bus. Wk., July 8, 1991, at 62. In fact, as Dwyer further points out, "[o]f all the groups eligible for preferential hiring, women have fared the best." Id. (citing Census Bureau statistics revealing that in 1990 women comprised $45 \%$ of the labor force, compared to $10.1 \%$ for blacks, $2.6 \%$ for Asians and $7.5 \%$ for Hispanics).

34. Laurence Tribe describes de jure discrimination as "[d]eprivations of equality by governmental classifieation and thus different treatment" and de facto discrimination as "deprivations attributable to failure to classify and hence treat differently." LAURENCE TRIBE, AMERICAN CONSTITUTIONAL LAW § 16-1, at 1439 (2d ed. 1988).

The most outrageous and debilitating discrimination against blacks occurred during the slavery and Jim Crow eras. MAGUiRE, supra note 31, at 131-33. As slaves from 1619 to 1865, "blacks were held in degrading bondage, possessing no rights that whites were bound to respect." Id. at 132. During the Jim Crow era, the government denied blacks equal voting privileges and mandated the separation of blacks and whites in public facilities. $I d$. at 133.

35. See supra text accompanying note 1.

36. See John E. Nowak Et AL., Constitutional Law 603 (3d ed. 1986) (“' ‘B]enign' discrimination [is] the use of racial classifications to benefit rather than burden particular racial or ethnic minorities.").

37. Black's Law Dictionary 59 (6th ed. 1990). Numerous practices have been described as affirmative action. For instance, Professor Van Alstyne suggests that there are at least five distinct concepts of affirmative action:

(1) Acting affirmatively toward each human being as a person and as an individual entitled to one's regard unbounded by his or her race; (2) Acting affirmatively to ensure that racial discrimination does not occur anywhere within one's field of control; (3) Acting additionally to eliminate gratuitous obstructions otherwise tending to limit each person's eligibility or opportunities; (4) Electing anıong alternative nondiscriminatory political choices those likely to be of most significant use to ethnic minority persons; and (5) [T] he practice of requiring each person to be identified racially, preeisely for the purpose of distinguishing that person's civil rights from those of others.

William W. Van Alstyne, Affirmative Action and Racial Discrimination Under Law: A Preliminary Review, in 1 U.S. COMm'N ON Civil Rights, Selected AfFiRmative Action Topics IN EMPLOYMENT AND BUSINESS SET-ASIDES 180, 186 (1985). 
also frequently described as "reverse discrimination."38 However, the phrases "reverse discrimination" and "benign discrimination" are criticized as an inappropriate and misleading way to describe affirmative action. ${ }^{39}$ When considering the various different definitions and labels for affirmative action, it is important to keep in mind that the goal of affirinative action is not to insult or injure white inales or to place thein in an inferior status in relation to minorities, but to aid minorities only to a limited degree and in limited circumstances for the purpose of furthering racial equality.

Pinning down a precise definition of affirmative action is difficult because the phrase describes a multitude of practices that vary significantly from industry to industry and from institution to institution. ${ }^{40}$ For purposes of this Note it is only necessary that the reader understand the difference between two generally recognized forins of affirmative action: "quotas" and "preferential treatinent" measures.41 Thus, contrary to popular behef, affirmative action is not synonymous with quotas.

Other commentators suggest that there are two basic concepts of affirmative action, remedial and preferential: "Remedial affirmative action involves such things as collaboration with minority organizations and media, the use of minority recruiters, job recruitment at black colleges, revision of testing procedures, advertising targeted to minority groups, new training programs, and remedial education. . . . Preferential affirmative action involves the use of numerical goals and timetables." MAGUIRE, supra note 31 , at 30.

38. See Barry R. Gross, General Introduction, in Reverse Discrimination 3, 3 (Barty Gross ed., 1977) ("[R]everse discrimination is giving special or preferred treatment to persons who are members of racial or religious or ethnic groups or a sex against whose membership generally unjust discrimination was or is being practiced.").

39. Maguire argues that the media's use of the teru reverse discrimination to refer to affirmative action "is doing a disservice to truth by publishing and implanting a false and distorting symbol in the popular imagination." MAGUIRE, supra note 31, at 169 . In her dissenting opinion in Metro Broadcasting, Inc. v. FCC, 110 S. Ct. 2997, 3028 (1990), Justice O'Connor rejects the description of the FCC mimority ownership policies as berign. She argues that the term " benign' carries with it no independent meaning, but reflects only acceptance of the current generation's conclusion that a politically acceptable burden, imposed on particular citizens on the basis of race, is reasonable." Id. at 3033.

40. Professor Clay Simith provides a good illustration of the variety of forms that affirmative action might take in the employment context:

Some examples of appropriate means to affirmatively eliminate employment barriers . . . include: A recruitment program designed to attract qualified members of the group in question; A systematic effort to organize work and redesign jobs in ways that provide opportunities for persons lacking 'journeyman' level knowledge or skills to enter and, with appropriate training, to progress in a carecr field; Revamping selection instruments or procedures whicli have not yet been validated in order to reduce or eliminate exclusionary effects on particular groups in particular job classifications; The initiation of measures designed to assure that members of the affected group who are qualified to perform the job are included within the pool of persons from which the selecting official makes the selection.

J. Clay Smith, Jr., Perspectives on Equal Employment Opportunity Litigation: Review: Affirmative Action, 27 How. L.J. 495, 496 (1984) (footnotes omitted).

41. See Nowak, supra note 36 , at 604 . Unless otllerwise specified, the use of the term affirmative action in this Note refers to either quotas or preferential treatment measures: 
"Quotas" reserve opportunities and benefits exclusively for qualified members of designated minority groups. ${ }^{42}$ "Preferential treatment," on the other hand, allows an individual's status as a minority to be considered as a positive factor among other factors when allocating opportunities and benefits. ${ }^{43}$ Although some contend that there are other forms of affirmative action, quotas and preferential treatment (or racial preferences) are the only two forms of affirmative action that have been "the subject of serious constitutional challenge." 44

There was soine disagreement in Metro Broadcasting, Inc. v. FCC ${ }^{45}$ as to whether the two FCC minority ownership policies at issue were quotas or preferential treatment measures. ${ }^{46}$ In reference to one of the policies, the inajority opinion states that it was "not a quota or fixed quantity set-aside." 47 Although the inajority opinion does not explicitly refer to the other FCC policy as not being a quota or set-aside, it does

In judging the constitutionality of affirmative action programs, a distinction must be drawn between two basic forms of affirmative action. A quota may be set reserving a specific number of places for ininority members and a specific number for nonminority tnembers. Alternatively, separate standards may be set giving preferential treatınent to ininority members without the use of a quota.

Id.

Frequently, institutious employ goals (numerical targets) and timetables (deadlines) in conjunction with affirmative action measures as a means of guiding their hiring or promotional system. However, goals and timetables are not affirmative action measures because unlike quotas and preferential treatment measures they do not entail allocating legally significant opportunities and benefits to individuals based on their race or minority status. See Clarence Thomas, Affirmative Action Goals and Timetables: Too Tough? Not Tough Enoughl, 5 YALE L. \& POL'y REV. 402, 402 n.1 (1987) ("A 'goal' is a numerical target, usually expressed as a percentage, for the hiring or promotion of persons of a particular group. 'Timetables' are the deadlines for reaching the numerical goals."). An institution may respond to goals and timetables by doing nothing more than seeking to identify minority applieants or actively encouraging minorities to apply for positions.

42. See Steven Emanuel, Constrrutional LAw 268 (1989) ("A racially-based quota is an inflexible number of admissions slots, dollar amounts, or other 'goodies' set aside for minorities. For instance, a quota exists if the state says that $1 / 2$ of all new hires in the police departinent must be black, or if it says that $20 \%$ of all seats in a public university's law school class will be set aside for Blacks or Hisparics."). As refiected in this definition, the term "set aside" is frequently used to describe affirmative action measures that reserve opportunities or benefits exclusively for minorities.

43. Without reserving positions or benefits exclusively for minorities, many colleges and universities employ preferential treatment ineasures where factors such as race, gender, and ethnic origin are considered positive factors in admissions and scholarship determinations. For example, Duke Law School employs what it describes as a "faculty-initiated affirmative action plan for minority admissions" where "special care is taken in evaluating applications from inembers of minority groups who traditionally have not been well represented in the legal profession." BULLETIN of DUKe UNIVERSITY 1989-90, at 39 (1989).

44. NowAK, supra note 36 , at 604 .

45. 110 S. Ct. 2997 (1990).

46. See infra text accompanying notes 127-37.

47. See Metro Broadcasting, 110 S. Ct. at 3027. 
stress that the pohicy has a limited effect on the FCC's award of broadcast licenses. ${ }^{48}$ However, in Justice Kennedy's dissenting opinion, he refers to both policies as "quotas." 49 Botli of the FCC minority ownership policies should be described as preferential treatnient nieasures because they are not dispositive of whether minorities will be granted any broadcast licenses. ${ }^{50}$ The policies neither guarantee nor set-aside licenses for minority apphicants.

\section{The Law of Affirmative Action}

To understand the law of affirmative action and the Metro Broadcasting decision one inust understand the Equal Protection Clause of the Fourteenth Amendnient and the rationale behind the Suprenie Court's prior treatınent of race-conscious governinent affirmative action policies. Part II addresses the legislative history of the Fourteenth Amendment, explains the particular application of the Equal Protection Clause to affirmative action ineasures, and addresses the question of whether the Fourteenth Amendment prohibits the governnient fron1 using affirmative action. This Part also discusses Fullilove v. Klutznick ${ }^{51}$ and City of Richmond v. J.A. Croson Co. ${ }^{52}$ two important Supreme Court cases relied on by the Metro Broadcasting Court.

\section{A. The History of the Fourteenth Amendment}

Enacted shortly after the Civil War in 1868, the Fourteenth Amendinent was desigued primarily to secure freedom and equal treatment for ex-slaves by outlawing state discrimination against recently eniancipated blacks. ${ }^{53}$ Even though the prohibitions of the annendment were desigued with blacks in mind, the annendment protects all individuals within the state's jurisdiction regardless of their race, creed, or national origin. ${ }^{54}$ For the nioment, it is necessary to consider only Section 1 of the Fourteenth Amendment, which provides, in part, that no state shall deny to any person within its jurisdiction the equal protection of the laws. ${ }^{55}$ This

48. See id. at 3004.

49. See id. at 3045 (Kennedy, J., dissenting).

50. See infra text accompanying notes 127-37.

51. 448 U.S. 448 (1980).

52. 488 U.S. 469 (1989).

53. See McLaughlin v. Florida, 379 U.S. 184, 192 (1964) ("[T]he central purpose of the Fourteenth Amendment was to eliminate racial discrimination emanating from official sources in the States.").

54. See Yick Wo v. Hopkins, 118 U.S. 356, 369 (1886) (noting that the provisions of the Fourteenth Amendment are "universal in their application, to all persons within the territorial jurisdiction, without regard to any differences of race, of color, or of nationality").

55. Section 1 of the Fourteenth Amendment provides in full: 
clause applies to classifications that affect the legal rights and obligations of individuals. ${ }^{56}$

The exact guarantees of the Equal Protection Clause are subject to dispute, but it is generally accepted that the clause protects individuals from intentional and arbitrary discrimination by the state. 57 In otlrer words, the clause requires that all persons under like circumstances and conditions be treated alike and given equal protection of the laws in the enjoyment of personal riglits, sucls as the right to life, liberty, property, and the pursuit of happiness. ${ }^{58}$ For example, one coinmentator explains that intentional racial segregation in public schools violates the equal protection riglts of blacks because blacks and whites are similarly situated witl respect to public education, but are not similarly treated. ${ }^{59} \mathrm{~A}$ statute that requires voters to personally come to the polls regardless of their physical capacity to do so is also a denial of equal protection in that persons with disabilities are treated differently witl respect to voting. 60

The Equal Protection Clause applies directly to states and inunicipalities and indirectly to the federal government through the Due Process Clause of the Fifth Amendinent, ${ }^{61}$ binding the legislative, executive, and judicial branches of government as well as adinimistrative agencies. ${ }^{62}$ Actions of private persons or entities, however, cannot be reached by the Equal Protection Clause unless there is significant interplay between the government and the private activity. ${ }^{63}$

All persons born or naturalized in the United States and subject to the jurisdiction thereof, are citizens of the United States and of the State wherein they reside. No State shall make or enforce any law which shall abridge the privileges or immunities of citizens of the United States; nor shall any State deprive any person of life, liberty, or property, without due process of law; nor deny to any person within its jurisdiction the equal protection of the laws.

U.S. CONST. amend. XIV, § 1.

56. See Nowak, supra note 36 , at 519.

57. See 16A AM. JUR. 2D Constitutional Law § 738 (1968).

58. See id.:

The phrase 'equal protection of the laws' has not been precisely defined. In fact, the phrase is not susceptible of exact delimitation, nor can the boundaries of the protection afforded thereby be automatically or rigidly fixed. In other words, no rule as to what may be regarded as a denial of the equal protection of the laws which will cover every case can be formulated, and no test of the type of cases involving the equal protection clause of the Constitution can be infallible or all-inclusive.

Id. $\S 736$.

59. See Emanuel, supra note 42, at 218; see also TRIBE, supra note 34 , $§ 16-1$, at 1438 .

60. See EMANUEL, supra note 42, at 218; see also Tribe, supra note 34, §16-1, at 1438.

61. See 16A AM. Jur. 2D Constitutional Law $§ 741$ (1968) ("[I]f a classification would be invalid under the equal protection clause of the Fourteenth Amendment, it is also inconsistent with the due process requirement of the Fifth Amendment."); see also Bolling v. Sharpe, 347 U.S. 497 (1954).

62. See 16A AM. JUR. 2D Constitutional Law $\$ 742$ (1968) (noting that it is well settled that the Equal Protection Clause "cover[s] all the instrumentalities by which the state acts").

63. See Gilmore v. Montgomery, 417 U.S. 556 (1974) (holding that the Equal Protection Clause does not prohibit individual invasion of individual rights). 
Because everyone has a right to equal protection of the laws, a raceconscious classification must be assessed under the Equal Protection Clause when it permits or mandates, as does affirmative action, that minorities and non-minorities be treated differently regarding legally significant rights, benefits, and opportunities.

\section{B. Standards of Review Under The Fourteenth Amendment}

In determining whether a classification is consistent with the Equal Protection Clause, courts must look to whether the classification amounts to invidious, arbitrary, or unreasonable discrimination. This determination is made by using one of three standards of constitutional review:64 the "rational relationship test," the "strict scrutiny test," and the "intermediate test." 65

The Court typically apphies the rational relationship test when faced with statutes that involve classifications relating to economic issues. Under this test, the Court will only seek to determine "whether it is conceivable that the classification bears a rational relationship to an end of government which is not prohibited by the Constitution."66 This is the earliest approach to equal protection review employed by the Court and is the least probing of the three tests. Apphication of this standard of review generally results in the classification being upheld. ${ }^{67}$

The strict scrutiny test is typically applied when the government makes classifications based on race, national origin, or which affect a fundamental right, such as the right to vote. ${ }^{68}$ Under this test, the classification will be upheld only if it is "necessary" to promote a "compelling" or "overriding" governmental imterest. ${ }^{69}$ This is the most probing standard of equal protection review. Statutes that satisfy the strict scrutiny test must have an extremely important objective, and the government must

64. See NowaK, supra note 36 , at 530.

65. See id. at 530-33. According to Justice Marshall, when applying the above standards of review, the Court generally considers three things: "the character of the classification in question; the individual interests affected by the classification; and the governmental interests asserted in support of the classification." Dunn v. Blumstein, 405 U.S. 330, 335 (1972).

66. NowAK, supra note 36 , at $\mathbf{5 3 0 .}$

67. See Jerome A. Barron \& C. Thomas Dienes, Constitutional Law 159 (1986) ("The traditional approach to equal protection review has been inarked by extreme judicial self-restraint and a marked concern for limiting the judicial role vis a vis the legislature."). For an illustration of how this standard of review has been einployed by the Court, see New Orleans v. Dukes, 427 U.S. 297 (1976) (applying the rational relationship standard in holding that a grandfather provision of an ordinance that prohibited pushcart food sales did not violate the Equal Protection Clause).

68. See BARRON \& DIENES, supra note 67, at 164-82. For an illustration of how this standard of review has been employed by the Court, see Loving v. Virginia, 388 U.S. 1 (1967) (applying the strict scrutiny test in holding that Virginia's anti-nniscegenation law violated the Equal Protection Clause).

69. See Nowak, supra note 36 , at 530 . 
"show a close relationship between the classification and promotion of a compelling or overriding interest."70

The third standard of review is the intermediate test, and has traditionally been applied in cases involving gender and illegitimacy. ${ }^{71}$ To satisfy the intermediate test, a classification must serve an "important governmental objective" and inust be "substantially related" to the achievement of such an objective.72 This standard is more probing than the rational relationship test, but less probing than the strict scrutiny test. A statute that satisfies tlie intermediate standard of review nust be important, but the fit between the means and ends of the statute need not be extreinely tight.

\section{The Fourteenth Amendment and Affirmative Action}

Soine judges and legal scliolars believe that regardless of its nature or intent, government-enacted affirmative action programs are a per se violation of the Constitution because the Equal Protection Clause prohibits the government from treating people differently solely on account of their race or minority status. This view is derived from a behef that our Constitution is "color-blind" and that the Framers of the Fourteenth Amendinent intended it to bar discrimination of all kinds, regardless of the ends souglit to be achieved. ${ }^{73}$ Altliougl1 articulated in a variety of ways, Justice Harlan's dissenting statenent in Plessy v. Ferguson is the inost cominonly cited expression of this view:

Our Constitution is color-blind, and neither knows nor tolerates classes among citizens ... [who] are equal before the law.... The law regards man as man, and takes no account of his surroundings or of his color when his civil rights as guaranteed by the supreme law of the land are involved. ${ }^{74}$

A more contemporary expression of this view, directly addressing the issue of government affirmative action, is expressed by Professor Van Alstyne:

[T] here is nothing in the Constitution that licenses the national government to establish racial shares, to legitimate measuring the worth of

70. Id.

71. See Barron \& Dienes, supra note 67, at 183-95. For an illustration of how the Court has employed this standard of review, see Craig v. Boren, 429 U.S. 190 (1976) (applying the intermediate test in holding that an Oklahoma law that permitted women to purchase $3.2 \%$ beer at age 18 but that required men to be 21 to make the same purchase violated the Equal Protection Clause).

72. Nowak, supra note 36, at 532.

73. Justice Stewart expressed this view in his dissenting opinion in Fullilove v. Klutznick, 448 U.S. 448 (1980), where he was joined by Justice Rehnquist. See id. at 523 (Stewart, J., dissenting). This view was also embraced by Justice Scalia in his concurring opinion in City of Richmond v. J.A. Croson Co., 488 U.S. 469, 521 (1989).

74. Plessy v. Ferguson, 163 U.S. 537, 559 (1896) (Harlan, J., dissenting). 
people by their race, or to tender entitlements by race. . . [T]o treat any person less well than another or to favor any more than another for beimg black or white or brown or red, is wrong. ${ }^{75}$

Those who disagree with this view argue that the legislative history and early interpretations of the Fourteenth Amendment provide no foundation for this position. Addressing the question of whether the Equal Protection Clause bars the government froin adopting affirmative action policies, Professor Tribe argues:

The principle that race may be taken imto account by a government body at least for the purpose of remedying past racial discrimination reasonably believed, by that body, to have distorted the situation that it would otherwise confront seeins compatible not only with the text but with the historical intent of the framers of the fourteenth amendment. Such affirmative action is compatible with the framers' intent regardless of whether that intent is defined in specific terms, by exainining the practices those framers evidently deemed coinpatible with the amendment, or in general terms, by explicating the concept of equality that the framers seemingly enacted into law. ${ }^{76}$

Another scholar notes that Congress's adoption of numerous social welfare programs from the post Civil War period throughout Reconstruction reveals that the Framers of the Fourteenth Amendment did not intend the Amendment to bar the government from enacting race-conscious classifications. ${ }^{77}$ According to Professor Schnapper:

The race-conscious Reconstruction programs were enacted concurrently with the fourteentli amendment and were supported by the saine legislators who favored the constitutional guarantee of equal protection. This history strongly suggests that the framers of the ainendinent could not have intended it generally to prohibit affirmative action for blacks or other disadvantaged groups. ${ }^{78}$

Those who contend that the Framers of the Fourteenth Ainendment did not intend to bar the government from enacting legislation based solely on racial classifications appear to have on their side the weight of constitutional history, and more importantly, current constitutional interpretation. Supreme Court precedent supports the view that the Equal

75. William W. Van Alstyne, Rites of Passage: Race, the Supreme Court, and the Constitution, 46 U. CHI. L. REV. 775, 809-10 (1978-1979); see also AlEXANDER M. BICKEL, THE MORALITY OF CONSENT (1975).

76. TRIBE, supra note $34, \S 16-22$, at 1525 (footnotes omitted).

77. See Eric Schnapper, Affirmative Action and the Legislative History of the Fourteenth Amendment, 71 VA. L. REv. 753, 754 (1985). Schnapper presents a comprehensive and detailed account of the congressional debate surrounding the enactment of the Fourteenth Amendment and race-conscious social welfare programs of the period.

78. Id. Schnapper notes that the inost important of the social welfare programs favoring blacks was the Freedmen's Bureau, which was created by Congress in 1866 and provided economic, educational, and other forms of aid to newly freed black Americans to help in their transition from slavery to freedom. See id. 
Protection Clause embodies the principle of equality of rights, but does not prohibit the government from treating people differently based on race, gender, or any other classification that furthers a legitimate govern1nent purpose. ${ }^{79}$ Hence, laws that benefit or burden individuals differently based on their race, gender, or national origin do not automatically violate the Equal Protection Clause. ${ }^{80}$ Legislative classifications need only be "based upon material and substantial differences having a reasonable relation to the objects or persons dealt with and to the public purpose sought to be achieved by the legislation imvolved."81 The government is only prohibited from making classifications that are unreasonable, arbitrary, or invidious. ${ }^{82}$

\section{The Supreme Court and Government-Mandated Affirmative Action Policies}

Prior to the Supreme Court's decision in Metro Broadcasting, the Court had dealt with the issue of affirmative action on at least twenty occasions. ${ }^{83}$ This Note focuses on government affirmative action, which refers to legislation that requires institutions to employ affirmative action

79. See, e.g., Stebbins v. Riley, 268 U.S. 137 (1925); Snowden v. Hughes, 321 U.S. 1 (1943); Salyer Land Co. v. Tulare Lake Basin Water Storage Dist., 410 U.S. 719 (1973).

80. See 16A AM. JUR. 2D Constitutional Law \& 738 (1979):

The Supreme Court has pointed out that the guaranty of equal protection of the laws is not one of equality of operation or application of state legislation upon all citizens of a state. Hence, laws need not affect every man, woman, and child exactly alike in order to avoid the constitutional prohibition against inequality.

Id. (footnotes omitted).

81. Id. (footnotes omitted).

82. Id.; see also Loving v. Virginia, 388 U.S. 1, 8-9 (1967); Craig v. Boren, 429 U.S. 190, 204 (1976); City of New Orleans v. Dukes, 427 U.S. 297, 303-04 (1976).

83. Burt Neuborne, Notes For The Restatement (First) Of The Law Of Affirmative Action: An Essay In Honor Of Judge John Minor Wisdom, 64 TuL. L. REv. 1543, 1543 (1990).

In addition to the categories of race- and gender-conscious classifications, affirmative action cases can be broken down into three additional categories: judicially imposed; voluntarily enacted; and legislatively mandated.

When affirmative action is judicially imposed, a court orders a party, pursuant to its powers under section 706(g) of the Civil Rights Act of 1964, 42 U.S.C. $\$ 2000 \mathrm{e}-5(\mathrm{~g})$ (1988), to enact affirmative action policies as a remedy for proven discrimination.

Voluntarily enacted affirmative action refers to the institutional practice of implementing affirmative action policies as a means of eradicating the effects of prior discrimination against minorities without being required to do so. See Smith, supra note 40:

Both private enterprise and labor unions have utilized voluntary affirmative action measures. They have done so when a self-evaluation of past and present employment practices and an analysis of the workforce compared with the available qualified labor pool, indicated that something other than mere chance may have been responsible for explaining the under-participation of qualified minorities and females in the company's workforce.

Id. at 498-99.

For a discussion of legislatively mandated affirmative action see MrCHAEL J. ZIMMER ET AL., Cases and Materials on Employment Discrimination 943-44 (2d ed. 1988). See also Smith, supra note 40 , at 497. 
measures. ${ }^{84}$ Prior to Metro Broadcasting, the Court addressed the issue of government affirmative action (legislatively and judicially imposed) on only seven occasions. ${ }^{85}$ The holdings and the equal protection analysis employed by the Court in two of these seven cases, Fullilove v. Klutznick ${ }^{86}$ and City of City of Richmond v. J. A. Croson Co. ${ }^{87}$ are crucial to understanding the Metro Broadcasting decision and race-conscious government affirmative action. ${ }^{88}$

1. Fullilove v. Klutznick. Prior to Metro Broadcasting, Fullilove was the only Supreme Court decision specifically upholding the authority of Congress to enact affirmative action policies. In Fullilove, a plurality of the Court upheld a minority set-aside ${ }^{89}$ provision of the congressionally enacted Public Works Employment Act (PWEA). ${ }^{90}$ The provision required states and mumicipalities receiving public works grants from the federal government to use at least ten percent of grant funds to procure services or supphies from minority owned businesses. ${ }^{11}$ PWEA was cliallenged by several associations of construction contractors and subcontractors who alleged that they "sustained economic injury" because of the enforcennent of the minority set-aside provision. ${ }^{92}$ Specifically, they claimed that the provision violated the Equal Protection Clause of the Fourteentlı Amendment and the Due Process Clause

84. Although technically speaking judicially imposed affirmative action is a form of government affirmative action, this Note uses the phrase "government affirmative action" to mean only legislatively mandated and not judicially imposed affirmative action.

85. Neuborne, supra note 83 , at 1543 n.1, 1544 n.4. The seven cases are: City of Richmond v. J. A. Croson Co., 488 U.S. 469 (1989); Umited States v. Paradise, 480 U.S. 149 (1987); Local 28, Shect Metal Workers v. EEOC, 478 U.S. 421 (1986); Wygant v. Jackson Bd. of Educ., 476 U.S. 267 (1986); Fullilove v. Klutznick, 448 U.S. 448 (1980); Regents of the Univ. of Cal. v. Bakke, 438 U.S. 265 (1978); Kahn v. Shevin, 416 U.S. 351 (1974). The Court rendered a majority opinion in only two of these cases, Croson and Kahn. Neuborne, supra note 83, at 1544 n.4.

86. 448 U.S. 448 (1980).

87. 488 U.S. 469 (1989).

88. This Note does not critique the Court's decisions in Fullilove or Croson. Instead, these cases are discussed only in so far as they shed light on the Court's decision in Metro Broadcasting.

89. The formal title for the set-aside provision is "minority business enterprise" or "MBE" provision. The provision defined minorities as "Negroes, Spanish-speaking, Orientals, Indians, Eskimos, and Aleuts." Fullilove, 448 U.S. at 448.

90. Public Works Einployment Act of 1977, Pub. L. No. 95-28, 91 Stat. 116 (1977). Chief Justice Burger delivered the opinion, in which Justice White and Justice Powell joined. Fullilove, 448 U.S. at 453. Justice Powell also filed a concurring opinion. Id. at 495 . Justice Marshall concurred in the judgment and filed an opinion in which Justice Brennan and Justice Blackmun joined. Id. at 517. Justice Stewart dissented and filed an opinion in which Justice Rehnquist joined. Id. at 522. Justice Stevens also dissented and filed an opinion. Id. at 532.

91. Fullilove, 448 U.S. at 454.

92. See id. at 455 . 
of the Fifth Amendment. ${ }^{93}$ A federal district court upheld the provision $^{94}$ and the Court of Appeals for the Second Circuit affirmed.95 The case was appealed to the Supreme Court, where the Justices wrote five opinions and analyzed the set-aside provisions based on several different standards of constitutional review.

In his opinion announcing the judgment of the Court, Justice Burger did not use any of the three traditional equal protection standards of review. He stressed that " "great weight [should be accorded] to the decisions of Congress" " even when federal legislation implicates the fundamental rights protected by the Equal Protection Clause. ${ }^{96}$ Although Justice Burger stated that racial classifications required "close examination," Congress when it enacts such measures because of its authority under Section Five of the Fourteenth Amendment to create legislation " 'to secure the guarantees of the Fourteenth Amendment." "99 Justice Burger stated that the set-aside should be upheld if the Court was "satisfied that the legislative objectives and projected admimistration give reasonable assurance that the program will function within constitutional limitations." 100 Applying the above standard, he concluded tlat Congress had acted appropriately im attenipting to renredy discrimination agamst ininority contractors througl a minority set-aside provision that was "narrowly tailored to the achievement of that goal."101 In reaching this conclusion, Justice Burger was influenced by the fact that the provision had a "limited scope," was enacted as a "strictly rentedial measure," and

93. Id.

94. See Fullilove v. Kreps, 443 F. Supp. 253 (S.D.N.Y. 1977).

95. See Fullilove v. Kreps, 584 F.2d 600 (2d Cir. 1978).

96. See Fullilove, 448 U.S. at 473.

97. Id.

98. Id.

99. Id. at 476 (quoting Katzenbach v. Morgan, 384 U.S. 641,651 (1966)). Justice Burger wrote extensively about Congress's powers under the Fourteenth Amendment to enact legislation:

A program that employs racial or ethnic criteria, even in a remedial context, calls for close examimation; yet we are bound to approach our task with appropriate deference to the Congress, a co-equal branch charged by the Constitution with the power to 'provide for the ... general Welfare of the United States' and 'to enforce, by appropriate legislation,' the equal protection guarantees of the Fourteenth Amendment.

Id. at 472 (citations onitted). Justice Burger went on to say, " Correctly viewed, $\S 5$ is a positive grant of legislative power authorizing Congress to exercise its discretion im determining whether and what legislation is needed to secure the guarantees of the Fourteenth Amendnient." "Id. at 476 (quoting Katzenbach, 384 U.S. at 651). Section Five of the Fourteenth Amendnient provides: "The Congress shall have power to enforce, by appropriate legislation, the provisions of this article." U.S. CoNsT. amend. XIV, $\$ 5$.

100. Fullilove, 448 U.S. at 490.

101. Id. at 480 . 
had appropriate safeguards to ensure that only qualified minority business enterprises were awarded contracts. ${ }^{102}$

Justice Powell, who concurred in the judgment and filed his own opinion, applied what appears to be strict scrutiny review and concluded that the set-aside is "justified as a remedy that serves the compelling governmental interest in eradicating the continuing effects of past discrimination identified by Congress."103 Justices Marshall, Brennan, and Blackmun also concurred in the judgment, and expressed their views in a separate opinion. They examined the set-aside by applying the intermediate test. ${ }^{104}$ They held that remedying the effects of past discrimination agamst minorities in the contracting industry was an iniportant governmental interest and that the use of a minority set-aside was substantially related to the achievennent of that interest, thus satisfying intermediate review. ${ }^{105}$

Justices Stewart and Rehnquist flatly rejected the set-aside provision without applying any standard of equal protection review and concluded that the set-aside was a per se violation of the Fourteenth Amendinent. 106 In their view, the constitution is color blind and thus prohibits classifications based solely on race. As stated by Justice Stewart:

Under our Constitution, the government may never act to the detriment of a person solely because of that person's race. The color of a person's skin and the country of his origin are immutable facts that bear no relation to ability, disadvantage, moral culpability, or any other characteristics of constitutionally permissible interest to government. ${ }^{107}$

Justice Stevens also dissented from the Court's judgment, but on narrower grounds than Justices Stewart and Rehnquist. Applying strict scrutiny review, Justice Stevens concluded that the set-aside should be invalidated because it was not "narrowly tailored" to benefit the proper minority groups and included a remedy that was overbroad. ${ }^{108}$

2. City of Richmond v. J.A. Croson Co. At issue in City of Richmond v. J. A. Croson, Co. ${ }^{109}$ was the Minority Business Utilization Plan, a minority set-aside designed by the city of Richmond to remedy the

102. See id. at $480-81$.

103. Id. at 496 (Powell, J., concurring) (footnote omitted).

104. See id. at 517-20 (Marshall, J., concurring).

105. See id. at 520-21.

106. See id. at 527-30 (Stewart, J., dissenting).

107. Id. at $\mathbf{5 2 5}$ (footnote omitted).

108. See id. at 552-55 (Stevens, J., dissenting).

109. 488 U.S. 469 (1989). 
effects of prior discrimination against minorities in Richmond's contracting industry. ${ }^{110}$ This set-aside was similar to the federal set-aside at issue in Fullilove. In fact, both a federal district court and a divided panel of the Court of Appeals for the Fourth Circuit upheld the Richinond plan based on the Supreine Court's reasoning and decision in Fullilove, finding no constitutionally significant distinction between the two set-aside provisions. ${ }^{111}$

The Richmond plan required prime contractors to subcontract at least thirty percent of the dollar anount of each of their contracts to at least one ininority owned business. ${ }^{112}$ The plan was challenged by a white prime contractor who claimed that the set-aside violated his right to equal protection of the laws. ${ }^{113}$ Relying on Fullilove to rebut this claim, the city contended that it was " "a perversion of federalism to hold that the federal government has a compelling interest in remedying the effects of racial discrimination in its own public works program, but a city government does not." "114 Applying strict scrutiny review, five inembers of the Court found that the plan did not achieve a compelling government interest. ${ }^{115}$

Writing for the majority, Justice O'Connor explained the Court's application of strict scrutiny review to the Richmond set-aside. First, she concluded that by failing to provide significant statistical evidence that its "non-minority contractors were systematically excluding minority

110. Id. at 477-78.

111. See J. A. Croson Co. v. City of Richmond, 779 F.2d 181 (4th Cir. 1985) (Croson I). In Croson, the Supreme Court first considered the appeal of the non-minority business contractors who challenged the initial court of appeal's judgment upholding the set-aside. J. A. Croson Co. v. City of Richmond, 478 U.S. 1016 (1986). The Court vacated that judgment and remanded the case for reconsideration in light of an intervening Supreme Court decision in Wygant v. Jackson Bd. of Educ., 476 U.S. 267 (1986). Id. On reinand, another divided panel of the Fourth Circuit struck down the plan as a violation of the Equal Protection Clause's strict scrutiny test. See J. A. Croson Co. v. City of Richmond, 822 F.2d 1355 (4th Cir. 1987) (Croson II). The Supreine Court then agreed to hear the city's appeal, this time issuing a full opinion invalidating the plan by a vote of 6-3, marking the first time that a majority of the Court agreed on the standard of review for race-conscious affirmative action measures. Croson, 488 U.S. at 511.

112. Croson, 488 U.S. at 477 . The plan defined minority business enterprises as including businesses based anywhere in the country where at least $51 \%$ of the business was owned and controlled by black, Spanish-speaking, Oriental, Indian, Eskimo, or Aleut citizens. Id. at 477-78.

113. See id. at $476-77$.

114. Id. at 489 (quoting Brief for Appellant 32 (footnote omitted)).

115. Six opinions were written by the Court. Justice O'Connor delivered the opinion of the Court, in which Chief Justice Rehnquist and Justices Kennedy and White joined in part. Id. at 476. Justices Stevens and Keunedy filed opimons concurring in part and concurring in the judgment. Id. at 511 ; id. at 518 . Justice Scalia filed an opinion concurring in the judgment. Id. at 520 . Justice Marshall filed a dissenting opinion in which Justices Brennan and Blackmun joined. Id. at 528. Justice Blackmun also filed a separate dissenting opinion in which Justice Brennan joined. Id. at 561. 
businesses froin subcontracting opportunities"116 the city failed to satisfy the first prong of strict scrutiny review-the need to show a compelling governmental interest to justify its minority set-aside plan. In fact, Justice O'Connor found that "none of the evidence presented by the city points to any identified discrimination in the Richmond construction industry."117 Among the evidence introduced by the city was a statistical study indicating that, although blacks coinprised fifty percent of the city's population, in the years immediately preceding the enactınent of the set-aside plan, only $0.67 \%$ of its prime construction contracts went to minorities. ${ }^{118}$

Justice O'Connor also concluded that the city failed to satisfy the second prong of strict scrutiny review because the plan was not necessary or narrowly tailored to reinedy the effects of past discrimination against the minority groups identified in the plan. As a basis for this conclusion, she noted that the city did not consider a race-neutral plan ${ }^{119}$ and that the plan entitled a preference to designated minority groups residing anywhere in the conntry, solely based on their status as minorities. ${ }^{120}$

The city argued that the Constitution did not provide the federal government with any greater authority than states and inunicipalities to reinedy the effects of discrimination against minorities. Justice O'Connor, in response, stated that Congress-pursuant to Section Five of the Fourteenth Amendinent-had greater authority than states and municipalities to enact race-conscious legislation:

Congress, unlike any State or political subdivision, has a specific constitutional mandate to enforce the dictates of the Fourteenth Amendment. The power to 'enforce' may at times also include the power to define situations whicli [Congress] determines threaten principles of equality and to adopt proplyylactic rules to deal witl those situations. ${ }^{121}$

116. Id. at 509.

117. Id. at 505 .

118. See $i d$ at $484-85$. The city also presented testimomial evidence from municipal officials indicating that minority business enterprises were severely underrepresented among trade associations and federal studies revealing nationwide discrimination against minorities in the contracting industry. See id. at 529.

119. Id. at 507.

120. See id. at $477-78$.

121. Id. at 490. As support for this pronouncement, Justice O'Comor cited and quoted froun Associated Gen. Contractors v. City and County of San Francisco, 813 F.2d 922 (9th Cir. 1987), in which the court stated that "[t]he city is not just like the federal governinent with regard to the findings it inust inake to justify race-conscious remedial action." Id. at 929. She also cited and quoted Robert A. Bohrer, Bakke, Weber and Fullilove: Benign Discrimination and Congressional Power to Enforce the Fourteenth Amendment, 56 IND. L.J. 473 (1981), which stated that "Congress may authorize, pursuant to section 5, state action that would be foreclosed to the states acting alone." Id. at 512-13. 
In his dissenting opinion, Justice Marshall stated at the outset his behef that the Croson set-aside was "indistinguishable in all respects" from the federal set-aside upheld in Fullilove. ${ }^{122}$ Accordingly, Justice Marshall apphied intermediate review to the Croson plan as he did with the federal plan in Fullilove. Justice Marshall found that the statistical and testimonial evidence presented by Richmond was precisely the kind of evidence the Court had used in the past to uphold racc-conscious classifications desigued to reniedy the effects of past discrimination. ${ }^{123} \mathrm{He}$ also found that Richniond's interest in eradicating the effects of prior discrimination against minorities in the construction industry, coupled with its niterest in not allowing its funds to be used to reinforce and perpetuate the effects of racial discrimination, constituted an important governmental interest. ${ }^{124}$ Noting the "appropriately limited" nature of the Croson plan, such as its limited duration, its waiver provision, and its prospective application, Justice Marshall found the Richmond plan substantially related to the achievement of the city's interest in remedying the effects of prior discrimination against minorities. ${ }^{125}$ In fact, he noted that these were precisely the factors that led the Court to uphold the Fullilove set-aside. ${ }^{126}$ Thus, Justice Marshall would have upheld the setaside on the ground that it satisfied intermediate review in that it served an important governmental interest and was substantially related to the achievenient of that interest.

\section{METRo BROADCASTING AND GOVERNMENT AFFIRMATIVE ACtion Policies}

The Court's decisions in Fullilove and Croson provide inuch of the underlying rationale for the nrajority and dissenting views in Metro Broadcasting. Part III describes the FCC minority ownership policies at issue in Metro Broadcasting, analyzes the legal reasoning of the majority and dissenting views in the case, and touches on two of the more controversial political and philosophical objections to affirmative action embraced by the dissenters.

\section{A. Affirmative Action Policies at Issue in Metro Broadcasting}

Metro Broadcasting involved two cases consohidated on appeal. In the first case, Winter Park Communications, Inc. v. FCC, ${ }^{127}$ the Court

122. See Croson, 488 U.S. at 528 (Marshall, J., dissenting).

123. See id. at 529.

124. See id. at 536-39.

125. See id. at 548-51.

126. See id. at 549 .

127. 873 F.2d 347 (D.C. Cir. 1989). 
upheld the FCC's coinparative hicensing policy, which was designed to compensate for the "dearth of minority ownership in the broadcast industry" 128 by awarding an "enhancement for minority ownership in comparative proceedings for hicenses." 129 This procedure allowed the FCC to consider "minority ownership and participation in management ... as a 'plus' to be weighed together with all other relevant factors" 130 in comparative license proceedings for new broadcast stations. The dispute regarding this policy emerged when the FCC selected Rainbow Broadcasting over Metro Broadcasting to construct and operate a television station in Orlando, Florida. The FCC's selection of Rainbow Broadcasting was partly based on Rainbow's ninety percent Hispanic ownership, which the FCC deeined to outweigh the factors that favored Metro in the coinparative proceeding. Metro appealed the FCC's decision to the District of Columbia Circuit, where a divided panel of the court affirmed the decision. ${ }^{131}$

In the second case, Shurberg Broadcasting of Hartford, Inc. $v$. $F C C,{ }^{132}$ the Court upheld the FCC's "distress sale" 133 policy, which was designed "to increase minority opportunities to receive reassigned and transferred [broadcast] hicenses." 134 This policy allows "a broadcaster whose license has been designated for a revocation hearing, or whose renewal application has been designated for hearing, to assign the license to an FCC-approved minority enterprise."135 Congress and the FCC beheved that the distress sale pohicy would help minority enterprises "overcome the problein of madequate access to capital by lowering the sale price and the problem of lack of information by providing existing licensees with an incentive to seek out minority buyers." 136 The dispute regarding this policy einerged when Shurberg Broadcasting, a nonminority owned company, challenged the FCC's grant of permission to Faith Center, Inc. to sell its Hartford, Connecticut television station to a ininority broadcasting coinpany (Astroline Communications), under the distress sale policy. At the tinne Faith Center requested to sell to Astroline, Shurberg had an application pending before the FCC to obtain

128. Statement of Policy on Minority Ownership of Broadcasting Facilities, 68 F.C.C.2d 979, 983 (1978).

129. Metro Broadcasting, Inc. v. FCC, 110 S. Ct. 2997, 3002 (1990).

130. Id. at 3005.

131. See Winter Park, 873 F.2d at 349.

132. 876 F.2d 902 (D.C. Cir. 1989).

133. Metro Broadcasting, 110 S. Ct. at 3005. The Court noted that "[a]s a general rule, a licensee whose qualifications to hold a broadcast license come into question may not assign or transfer that hicense until the FCC has resolved its doubts in a noncomparative hearing." Id.

134. Id.

135. Id.

136. Id. at 3024 . 
Faith Center's station under the comparative hicensing procedure. Shurberg contended that the distress sale policy violated its equal protection rights. A divided panel of the District of Columbia Circuit agreed with Shurberg and invalidated the distress sale policy. ${ }^{137}$

\section{B. FCC Minority Ownership Policies Upheld}

In Metro Broadcasting, five members of the Suprene Court voted to uphold the congressionally mandated FCC minority ownership policies that provided preferences to minority broadcasters in hicensimg decisions. ${ }^{138}$ Despite strong objections from four members of the Court, the majority concluded that the FCC policies satisfied intermediate equal protection review because they served "an important governmental objective" and were "substantially related to the achievement of the Government's interest." 139

1. Which Standard of Review? The majority opimion began with the assertion that it was of "overriding significance" that the FCC policies were "specifically approved-indeed, mandated-by Congress." 140 This statement touched on the most critical divergence between the majority and dissenting views of the FCC policies and provided the constitutional and analytical framework for the Court's analysis.

In upholding the FCC policies, the majority primarily relied on the Court's 1980 decision in Fullilove v. Klutznick, ${ }^{141}$ the only case that addressed the constitutionality of federal affirmative action programs. The Court viewed Fullilove as requiring intermediate review to assess the constitutionality of federal affirmative action programs. The majority relied on Fullilove because a plurality of that Court upheld a congressionally mandated minority set-aside prograin by applying a variety of constitutional review standards-none of which rose to the level of strict scrutiny review. ${ }^{142}$ The test for intermediate review was einployed by the Metro Broadcasting Court just as it was articulated in Fullilove: ${ }^{143}$ Racial classifications are permissible under the Equal Protection Clause if they

137. See Shurberg, 876 F.2d at 903.

138. Justices White, Marshall, Blackmun, and Stevens joined Justice Brennan's majority opinion. Metro Broadcasting, $110 \mathrm{~S}$. Ct. at 3002 . The sole concurring opinion briefly summarized the Court's reasoning. See id. at 3028 (Stevens, J., concurring).

139. Id. at $3010-11$.

140. Id. at 3008 .

141. 448 U.S. 448 (1980).

142. See id.; see also supra Part I(D)(1).

143. Justice Marshall wrote a concurring opinion in Fullilove explaining that the federal setaside at issue in that case should be reviewed under intermediate scrutiny. See Fullilove, 448 U.S. at 517-19. He was joined by Justices Brennan and Blackmun. See id. at 517. 
" 'serve important governmental objectives and are substantially related to achievement of those objectives." "144

Before discussing the Metro Broadcasting Court's application of the intermediate test to the FCC policies, the question of whether the majority correctly interpreted Fullilove must be addressed. In her dissent in Metro Broadcasting, Justice O'Co1mor ${ }^{145}$ flatly rejected the Court's position that Fullilove provided the apphicable standard of review for the FCC pohicies. Justice O'Colmor instead argued that Croson prescribes strict scrutimy review for the type of affirmative action provisions at issue in Metro Broadcasting. She began her opinion with the same directness and forcefulness as Justice Brennan's majority opinion, stating that "the Constitution requires that the Court apply a strict standard of scrutiny to evaluate racial classifications such as those contained in the challenged FCC distress sale and comparative licensing policies."146 Justice O'Colmor then advanced three arguments as to why the Court should not have apphed intermediate review to the FCC policies at issue in Metro Broadcasting. ${ }^{147}$

First, she argued that Fullilove involved the "exercise of Congress" powers under $\S 5$ of the Fourteenth Amendinent." 148 According to Justice O'Connor, Section Five of the Fourteenth Amendment provides Congress with unique powers to carry out the dictates of the Fourteenth Amendment and, more importantly, requires the Court to defer to remedial actions of Congress pursuant to this power by applying a more lenient standard of constitutional review. ${ }^{149}$ Therefore, under Justice O'Connor's argument, the FCC minority ownership policies should not have been reviewed under intermediate scrutiny because they were not mandated by Congress pursuant to its powers under Section Five of the Fourteenth Amendment.

The majority rejected Justice O'Connor's argument that Fullilove "rested entirely on Congress's powers under $\S 5$ of the Fourteenth Amendment."150 As support for its position, the majority correctly

144. Metro Broadcasting, 110 S. Ct. at 3008 (quoting Fullilove, 448 U.S. at 519 (Marshall, J., concurring in the judgment)). The Court stated expressly that "[w]e apply that standard today." Id.

145. Chief Justice Rehnquist and Justices Scalia and Kennedy joined Justice O'Connor's dissent. See id. at 3028 (O'Connor, J., dissenting). Justice Kennedy wrote a separate dissent, which was joined by Justice Scalia. See id. at 3044 (Kennedy, J., dissenting).

146. Id. at 3029 (O'Connor, J., dissenting).

147. See id. at 3031-32.

148. Id. at 3031 .

149. Justice O'Connor argued that "Croson indicated that the decision in Fullilove turned on 'the unique remedial powers of Congress under $\S 5$ ' [of the Fourteenth Amendment]." Id. (quoting City of Richmond v. J.A. Croson Co., 488 U.S. 469, 490 (1989) (opinion of O'Connor, J.)).

150. See id. at 3008 n.11. 
pointed out that Chief Justice Burger, who wrote the principal opinion in Fullilove, "expressly noted" that "Congress employed an amalgam of its specifically delegated powers" in enacting the federal set-aside provision at issue in Fullilove. ${ }^{151}$ The majority's interpretation of Justice Burger's opinion is supported by a careful reading of Fullilove. Not only does Justice Burger state that Congress was acting pursuant to a variety of its powers in enacting the Fullilove set-aside, he also stated that the provision was enacted "primarily [as] an exercise of the Spending Power" provided for under Article I, Section 8, Clause 1.152 Also, Justice Burger specifically noted which other congressional powers Congress used when it enacted the federal set-aside, and explamed Congress's basis for using those powers. ${ }^{153}$

Given the specificity of Justice Burger's opinion regarding the congressional basis for enacting the Fullilove set-aside, Justice O'Connor's contention that the Fullilove set-aside was not given strict scrutiny review precisely because it was enacted by Congress pursuant to its powers under Section Five of the Fourteenth Amendinent lacks support. In fact, the most persuasive support for Justice O'Connor's position was her own majority opinion in Croson in which she posited this view of Fullilove. ${ }^{154}$ Even if Justice O'Connor's argument were supported by Fullilove, it does not inake sense under these circumstances to distinguish between actions of Congress pursuant to its Section Five powers, and congressional action pursuant to soine other congressional power. If Congress deserves deference when it acts to achieve equal opportunity pursuant to its Section Five powers under the Fourteenth Amendment, it deserves the same deference when it takes similar action pursuant to its other constitutional powers.

Second, Justice O'Connor argued that Fullilove "apphes at most only to congressional measures that seek to remedy identified past discrimination,"155 whereas the FCC minority ownership policies were "not remedial in any sense."156 It is unclear how this argument is any different from Justice O'Connor's first argument; they both turn on the question of whether the Court upheld the federal set-aside in Fullilove

151. Id. (quoting Fullilove v. Klutznick, 448 U.S. 448, 473 (1980) (opinion of Burger, C.J.)).

152. Fullilove, 448 U.S. at $473-74$ (opinion of Burger, C.J.).

153. See id. at 475 ("We turn first to the Commerce Power."); id. at 476 ("[T]he objectives of the MBE program are within the power of Congress under $\S 5$ 'to enforce by appropriate legislation,' the equal protection guarantees of the Fourteenth Amendinent.").

154. See Croson, 488 U.S. at $490-91$.

155. Metro Broadcasting, 110 S. Ct. at 3031 (O'Connor, J., dissenting).

156. Id. 
because it was enacted by Congress as a remedial measure. ${ }^{157}$ This argument is yet another attempt to make Fullilove into a decision that turned on the remedial nature of the federal set-aside at issue. As explained above, this interpretation of Fullilove is mconsistent with the Court's reasoning in that case. As noted in Justice Stevens's concurring opinion in Metro Broadcasting, the majority did not view the FCC policies as remedial in nature. ${ }^{158}$ Nonetheless, the question of whether or not the FCC pohcies were remedial was largely irrelevant to the inajority because it interpreted Fullilove to provide the standard of review for all congressionally mandated affirmative action measures, regardless of whether they were designed to remedy discrimination or enacted pursuant to Congress's powers under Section Five of the Fourteenth Amendment. ${ }^{159}$

Finally, Justice O'Connor argned that "even if Fullilove apphed outside of Congress' $\S 5$ power" it still did not support the majority's use of intermediate review. ${ }^{160}$ As support for this position, she noted that six of the Justices voting im Fullilove "rejected intermediate scrutiny in favor of soine more strimgent form of review."161 Although Justice O'Connor correctly poimted out that a inajority of the Court in Fullilove rejected intermediate review, she failed to notice that a majority of the Justices voting in Fullilove also rejected strict scrutimy review for a more lenient standard. Even if the Court had employed this more lenient standard of review-albeit more strmgent than intermediate review-it is doubtful that a majority of the Court would have struck down the FCC policies since the apphication of these policies was far less expansive and burdensoine than the federal set-aside upheld in Fullilove and the Richmond setaside invalidated in Croson.

Justice O'Counor dissented in Metro Broadcasting because she beheved that the Court should have looked to Croson rather than Fullilove for guidance on the appropriate standard of review to apply to the FCC

157. In stating this argument, Justice O'Connor suggested that "Fullilove indicatcd that careful review was essential to ensure that Congress acted solely for remedial rather than other, illegitimate purposes." Id. (citing Fullilove, 448 U.S. at 486 (opinion of Burger, C.J.); id. at 498 (opinion of Powell, J.)).

158. Id. at 3028 (Stevens, J., concurring) ("Today the Court squarely rejects the proposition that a governmental decision that rests on a racial classification is never permissible except as a reinedy for a past wrong.").

159. Although the majority did not argue that the FCC policies were remedial, they did point out that Congress had determined that past inequality resulting from discrimination against racial minorities contributed to the lack of minority participation in the broadcasting industry. See id. at 3009-10. However, the majority went on to explain that Congress and the FCC "selected the ininority ownership policies primarily to promote programming diversity." Id. at 3010.

160. Id. at 3032.

161. Id.; see also Part $\Pi(\mathrm{D})(1)$. 
policies. ${ }^{162}$ The Court, however, appropriately rejected this view on the ground that Croson involved a "minority set-aside prograin adopted by a municipality" and thus did not "prescribe the level of scrutiny to be applied to a benign racial classification employed by Congress."163 The problenı with Justice O'Connor's position in Metro Broadcasting is that it was based on her narrow and erroneous interpretation of Fullilove, which slie nicorporated into lier Croson opinion.164 The niajority's view in Metro Broadcasting that the federal set-aside in Fullilove was enacted pursuant to an "amalgam" of congressional powers is correct. Accordingly, the Court concluded in Metro Broadcasting that Fullilove, not Croson, prescribed the standard of review to assess congressionally mandated affirmative action measures.

\section{Do the FCC Minority Ownership Policies Satisfy Intermediate} Review? A statute satisfies intermediate review if it serves an important governmental objective and is substantially related to the achievenient of such an objective. ${ }^{165}$ In Metro Broadcasting, the inajority held that the FCC minority ownership policies inet this requirement.

Specifically, the majority lield that Congress's interest in enhancing broadcast diversity was an important governmental objective in that the public at large benefits from having a diversity of programining on the airwaves. ${ }^{166}$ In fact, the majority's position was that the government lias a significant, identifiable, and justifiable interest in broadcast diversity. In support of its position, the majority cited a line of Supreme Court cases that established that the government may " put restraints on licensees in favor of others whose views sliould be expressed" ";167 that the welfare of the public benefits from " "the wildest [sic] possible dissenimation of information from diverse and antagonistic sources" "; 168 and that Congress lias the responsibility to "'assure that the public receives througl this mediuin a balanced presentation of information on issues of public importance that otherwise might not be addressed if control of the medium were left entirely in the hands of those who own and operate broadcasting stations." "169 The majority also found that Congress liad sufficient evidence indicating that the underrepresentation of minorities in the broadcasting industry was due to "past inequities stemining from

162. See Metro Broadcasting, 110 S. Ct. at 3032.

163. Id. at 3009.

164. See supra text accompanying notes $116-21$.

165. See supra text accompanying notes 71-72.

166. See Metro Broadcasting, 110 S. Ct. at 3009-10.

167. Id. at 3010 (quoting Red Lion Broadcasting Co. v. FCC, 395 U.S. 367,390 (1969)).

168. Id. (quoting Associated Press v. United States, 326 U.S. 1, 20 (1945)).

169. Id. (quoting FCC v. League of Wotnen Voters, 468 U.S. 364, 377 (1984)). 
racial and ethnic discrimination." 170 Based on these findings, the Court concluded that there was a "sufficient basis" for Congress to enact the FCC minority ownership pohicies. ${ }^{171}$

The majority also concluded that the FCC policies were substantially related to the objective of enhancing broadcast diversity and provided several reasons supporting this view. First, the Court accepted Congress and the FCC's conclusion that there is a nexus between increased minority ownership of broadcast stations and broadcast diversity. ${ }^{172}$ Second, the Court concluded that the policies were adopted only after "long study and painstaking consideration of all available alternatives."173 Finally, the Court was influenced by the fact that Congress and the FCC rejected the more expansive alternative of "setting aside certain frequencies for minority broadcasters"174 and envisioned that there would be "no need for further minority preferences once sufficient diversity has been achieved."175

The majority opinion in Metro Broadcasting is supported by welldocumented and long-standing FCC opinions and studies, as well as legislative and scholarly material. For example, the majority rehed on the FCC's 1978 Statement of Policy on Minority Ownership of Broadcasting Facilities, a report concluding that "[f]ull minority participation in the ownership and management of broadcast facilities results in a more diverse selection of programming."176 The Court also considered the circumstances under which the the FCC established its ininority preferences:

The FCC did not act precipitately in devising the programs we uphold today; to the contrary, the Commission undertook thorough evaluations of its policies three times-in 1960, 1971, and 1978-before adopting the minority ownership programs. In endorsing the minority ownership preferences, Congress agreed with the Cornmission's assessment that race-neutral alternatives had failed to achieve the necessary programming diversity. ${ }^{177}$

170. Id. at 3009-10.

171. See id. at 3010 .

172. See id. at 3011.

173. Id. at 3019.

174. Id. at 3023. This statement reflects the majority's view that the FCC policies are not quotas or set-asides, but preferential treatment affirmative action policies.

175. Id. at 3025.

176. Statement of Policy on Minority Ownership of Broadcasting Facilities, 68 F.C.C.2d 979, 981 (1978).

177. Metro Broadcasting, 110 S. Ct. at 3022-23. 
Despite the position of Justices O'Connor and Kennedy that the Metro Broadcasting Court acted improperly by assessing the FCC pohcies under intermediate review, they nevertheless concluded that the pohcies did not "survive even intermediate scrutiny."178 Justice O'Connor rejected the government's interest in increasing broadcast diversity as "simply too amorphous, too insubstantial, and too unrelated to any legitimate basis for employing racial classifications." 179 However, her attempt to distinguish the numerous Supreme Court cases that recognize a legitimate government interest in broadcast diversity is unpersuasive. According to Justice O'Connor, the government's interest in broadcast diversity is analogous to the government's interest in achieving minority role inodels for minority public school students, ${ }^{180}$ an interest which a plnrality of the Court rejected as insufficiently weighty in Wygant $v$. Jackson Board of Education. ${ }^{181}$ Justice O'Connor's comparison of the government's interest in minority role inodels to that of broadcast diversity is unconvincing given what little is known about the value of role model theories of education for blacks. Broadcast diversity is not only accepted in our society, but its value to society is well documented, as illustrated by the congressional and FCC material that was cited in the Metro Broadcasting opimon. ${ }^{182}$

Justice O'Connor further argued that the FCC policies were not substantially related to the achieveinent of broadcast diversity. Rejecting the majority's argument point by point, Justice O'Connor argued that there is no nexus between the race of a broadcast owner and the resulting programming; ${ }^{183}$ that the FCC and Congress did not employ all raceneutral means within their disposal to directly accomplish broadcast diversity; ${ }^{184}$ and that the policies are not limited in duration, but allowed for the "indefinite use of racial classifications" to obtain and maimtain the "appropriate mixtnre of racial views." 185

178. See id. at 3044 (O'Connor, J., dissenting); id. at 3045 (Kennedy, J., dissenting).

179. Id. at 3034 (O'Connor, J., dissenting).

180. See Metro Broadcasting, 110 S. Ct. at 3035-36 (O'Connor, J., dissenting).

181. 476 U.S. 267 (1986).

182. See Metro Broadcasting at 3011 (citing H.R. Conf. Rep. No. 97-765, 97th Cong., 2nd Sess. 45 (1982); Minority Ownership of Broadcast Stations: Hearing before the Subcommittee on Communications of the Senate Committee on Commerce, Science, and Transportation, 101st Cong., 1st Sess. 66 (1989) (testinnony of Roderick Porter, Deputy Chief, Mass Media Bureau of the FCC). As the majority noted, the benefits of broadcast diversity "are not linnited to the members of minority groups who gain access to the broadcasting industry by virtue of the ownership policies; rather, the benefits redound to all members of the viewing and listeming audience." Id.

183. See Metro Broadcasting, $110 \mathrm{~S}$. Ct. at 3041 (O'Connor, J., dissenting).

184. See id. at 3039.

185. Id. at 3035. 
One of Justice O'Connor's principal objections to the FCC minority ownership policies was that there was no nexus between minority ownership of broadcast stations and broadcast diversity. She argued that the FCC policies were based on the incorrect assumption that "race or ethnicity determines how they [minorities] act or think."186 Despite her inflexibility regarding this issue, she failed to marshall any evidenceeinpirical or otherwise-tliat supported her contention that the FCC ininority ownership policies cannot or do not enhance broadcast diversity. However, as reflected in Justice Brennan's majority opinion, the FCC and its allies presented substantial empirical and non-enipirical evidence underpinning the belief of Congress and the FCC that the minority ownership policies would enhance broadcast diversity. ${ }^{187}$ As the inajority noted, "the conclusion that there is a nexus between ninority ownership and broadcasting diversity-is corroborated by a host of enipirical evidence."188

In addition to the administrative and congressional niaterial that supports the FCC pohicies, there is also social science hiterature that supports Congress's and the FCC's contention that more minority broadcasters would, in the aggregate, lead to more diversity on the airwaves. Altlough not discussed in the majority opinion, one example is found in the field of psychology. According to psychologist Joseph White, there is a certain psychological perspective "reflected in the behavior, attitudes, life styles and cultural heritage of Black Americans,"189 which he describes as the "Afro-American world view." 190 White does not argue that all blacks think alike or that all whites think alike, but explains the African-American world view by contrasting it with the "Euro-American world view," a phrase he uses to describe the psychological perspective of white Americans. 191 In short, the "African-American world view," is reflected in black American behefs, assumptions, values, expressive patterns, and family life, among other things. ${ }^{192}$ For instance, White explains that black American music, in contrast to white American music, is generally made up of "ear-filling phrases that stir the innagination with lieavy reliance on tonal rhymes, symbolisn, figures of speech and

186. Id. at 3029 (O'Connor, J., dissenting).

187. See id. at $3017-18 \mathrm{nn}$. 31-34.

188. Id. at 3017.

189. Joseph L. White, The Psychology of Blacks: An Afro-American Perspective xi (1984).

190. Id. at 3. White explains that a world view "is a set of assumptions, beliefs, values, ideas, and behaviors shared by a particular group of people that are transmitted from one generation to the next." Id. at 2.

191. See id. at 11.

192. See id. at 3-4. 
personification." 193 He further adds that it is characteristic of the black singer or performer to "touch[] the collective experience base of the histeners by being honest and authentic, telling about life as it really is."194 One need not be a social scientist to recognize that there are significant differences between the cultures of blacks and whites in the United States that undoubtedly would be reflected in the programming of broadcast stations, depending on whether they are owned and nianaged by blacks or whites.

\section{The Philosophical and Political Debate over Affirmative Action}

Metro Broadcasting is typical of nost of the Supreme Court's jurisprudence on race-conscious affirmative action in that the decision reveals the intense political and philosophical differences among the Justices regarding the appropriateness and need for affirmative action. The views expressed by the various menibers of the Court indicate that there was more confusion and disagreement among thein regarding the pohitical and social issues surrounding affirmative action than about the appropriate standard of equal protection review to be applied to affirmative action policies. Professor Patricia Williams accurately describes this tension among the Justices in a recent comment on Metro Broadcasting:

Although the majority and the dissenters framed the issue in terms of disagreement about the standard of review, their underlying characterizations of the facts and weighing of the evidence were so polarized that the split probably would have remained even had they agreed on this doctrinal issue....

The intensity of these divisions is rooted in profound differences in political philosophy about the nature of group identity, individualism, and the role of the market. ${ }^{195}$

The dissenting opinions of Justices O'Connor and Kennedy, for instance, digressed froni the narrow issue of whether the specific goals and application of the FCC pohicies were justifiable based on precedent and the facts underlymg the case. Both of their opinions advanced broad constitutional, political, and philosophical argunients against affirmative action, instead of directly rebutting the evidence rehed on by the niajority as support for its position. For example, both Justices O'Counor's and Kennedy's opinions devote substantial attention to whether affirmative action stigmatizes minorities, ${ }^{196}$ whether it divides the nation, ${ }^{197}$ and

193. Id. at 29.

194. Id.

195. Patricia J. Williams, Metro Broadcasting, Inc. v. FCC: Regrouping in Singular Times, 104 HARV. L. REV. 525, 526 (1991).

196. See Metro Broadcasting, 110 S. Ct. at 3029 (O'Connor, J., dissenting). For a discussion of this argument, see infra Part III(C)(1). 
whether it benefits and burdens the wrong individuals. ${ }^{198}$ Yet the issue presented to the Court in Metro Broadcasting was inerely to determine whether the FCC minority ownership policies were constitutional. Deciding this question did not require the Court to consider these larger philosophical questions. The constitutionality of the FCC pohicies was capable of being determined by considering existing Supreme Court precedent and the evidence presented in support of the policies; whether the policies are indeed "good" for the people whoin they are intended to benefit is beside the point.

Metro Broadcasting reflects the difficulty judges have dealing with inatters of discrimination and equality of opporturity without preventing their political, social, and inoral values from affecting their perception of the case and the law governing the dispute. ${ }^{199}$ Yet judges have a duty and responsibility to keep their personal biases from impacting their decisions and from appearing to impact their decisions in ways that are inconsistent with controlling legal principles and precedent. Unfortunately, when confronted with the issues involved in cases like Metro Broadcasting, the Justices seein unable to prevent or even limit the degree to which their political and philosophical orientations directly affect their analyses and ultimate decisions. The following Sections briefly discusses two issues that arose in Metro Broadcasting that clearly influenced and divided the Justices in their assessinent of the constitutionality of the FCC policies.

1. Does the Stigma Associated with Affirmative Action Outweigh Its Benefit to Blacks and to Society? In their dissenting opinions in Metro Broadcasting, both Justices O'Connor and Kennedy referred to the ininority ownership policies at issue as having a stigmatizing effect on its minority beneficiaries. ${ }^{200}$ Justice Kennedy wrote that the FCC policies seein to be "based on the deineaning notion that ineinbers of the defined racial groups ascribe to certain 'minority views' " and that such policies

197. See id. (O'Connor, J., dissenting).

198. See id. at 3044 (Kennedy, J., dissenting). For a discussion of this argument, see infra Part III(C)(2).

199. As for the ability of judges to render value-neutral decisions on affirmative action, one scholar notes:

No objective standard exists whereby a judge may mechanically distinguish betwecn 'compelling' and 'important' state interests or between 'substantially related,' 'necessary,' or merely 'rational' legislative means. Because of this lack of standards, judicial implementation of the strict and intermediate scrutiny tests in affirmative action equal protection cases requires reliance on substantive values.

Michel Rosenfeld, Metro Broadcasting, Inc. v. FCC: Affirmative Action at the Crossroads of Constitutional Liberty and Equality, 38 UCLA L. REv. 583, 591 n.35 (1991) (citations ornitted).

200. See Metro Broadcasting, 110 S. Ct. at 3028 (O'Connor, J., dissenting); id. at 3044 (Kennedy, J., dissenting). 
"can foster the view that members of the favored groups are inherently less able to compete on their own."201 Similarly, Justice O'Connor argued that the FCC policies "may stigmatize" minority groups because they "einbody stereotypes that treat individuals as the product of their race." 202

Granted, Justices O'Connor and Kennedy are not alone, nor mcorrect, in asserting tliat affirmative action policies tend to stigmatize minorities who benefit from such policies. ${ }^{203}$ Despite the validity of this view, it is not a sufficient reason to reject affirmative action. Contrary to what Justices O'Connor and Kennedy apparently beheve, the stigma associated with affirmative action does not necessarily undermine its legitimacy and effectiveness. Indeed, the stigma that results froin affirmative action comes not from the use of racial preferences but from the deep-seated racial views and stereotypes that are triggered by the preferences.

There are at least two components to the affirmative action stigma argument: first, that blacks feel inferior and inadequate as a result of affirmative action's stigma; and second, that others view blacks as inferior or inadequate as a result of affirmative action. Before directly addressing these arguments, it slould be noted that whatever stigma blacks experience as a result of being the beneficiaries of affirmative action will vary depending on numerous factors, such as the type of institution enploying the policy, the nature of the policy itself, and the personality of the individual affected.

There is no systematic evidence that supports the claim that as a result of affirmative action blacks develop debilitating inferiority complexes. There is, however, evidence that shows that a majority of blacks support affirmative action to advance racial equality by affording blacks and other minorities an equal opportumity to compete for jobs, proinotions, and other opportunities. Consider a 1991 nationwide survey conducted by the Los Angeles Times, which reveals that $74.4 \%$ of blacks favor affirmative action, whereas only six percent of blacks are opposed to it. ${ }^{204}$ This survey also reveals that only four percent of blacks think

201. Id. at 3046 (Kennedy, J., dissenting).

202. Id. at 3029 (O'Connor, J., dissenting).

203. Professor Shelby Steele, a black English professor at San Jose State University and a leading critic of affirmative action, argues that affirmative action deınoralizes blacks. Shelby Steele, $A$ Negative Vote on Affirmative Action, N.Y. TIMES, May 13, 1990, at 46; see also Sonia Nazario, Many Minorities Feel Torn by Experience of Affirmative Action, WALL ST. J., June 27, 1989, at 1.

204. Ronald Brownstein, The Times Poll: Black, White Americans Split over Anti-Bias Laws, L.A. TIMEs, Nov. 5, 1991, at A1 (noting that the survey findings of this poll are "reinforced by findings of other polls").

A sinilar survey, conducted by Black Enterprise inagazine in 1990, revealed that $19.9 \%$ of blacks questioned thought that affirmative action was effective; $63.8 \%$ thought it was soinewhat effective; and $15.3 \%$ thought it was ineffective. Fifty-one percent of blacks questioned in that survey 
affirmative action goes too far, whereas sixty percent of blacks think it doesn't go far enough. ${ }^{205}$

Professor Randall Kennedy offers several insightful reasons why blacks overwhelmingly support affirmative action. First, blacks view affirmative action as "rather modest coinpensation for the long period of racial subordination suffered by blacks as a group."206 Second, blacks tend to be skeptical of the supposedly fair and objective criteria used to make competitive decisions regarding matters such as college admissions and proinotions. ${ }^{207}$ Finally, blacks are aware of the "thoroughly political" and "contestable" nature of meritocracy. 208

As for the claim that affirmative action causes others to view blacks as inferior, this contention is effectively countered by Richard Banks, who suggests that the "twisted racial history" of the United States, not affirmative action, is responsible for "black self-doubt and white suspicion":209

How could whites now beheve that blacks can achieve on their own when four centuries ago white Americans created an image of Africans as lazy, stupid and irresponsible? And after so long, how could blacks not believe that as well? ....

For most of this country's history, the nation's top universities practiced the most effective form of affirmative action ever; the quota was for 100 percent white males. But do we ever hear talk of white men runnimg around questioning their competence, doubting that they were 'truly qualified'? ?10

Although the stigma associated with affirmative action is a frequently voiced objection to its continued use, the proponents of this argument often exaggerate its impact. Also, the simcerity of this arguinent is questionable given that it is most often advanced by whites, many of whom feel victimized by affirmative action. Objecting to affirmative action because it stigmatizes blacks appears to reflect a concern that blacks are hurt, rather than helped, by affirmative action. But if this were indeed the case, a significant number of blacks would most likely be annong

thought that affirmative action will be necessary ten years from now, and $83.8 \%$ thought that black economic advancement had been affected by recent Supreme Court decisions that curtailed the use of affirmative action. Black Enterprise Survey, BLACK ENTERPRiSE, Aug. 1990, at 85, 86.

205. Brownstein, supra note 204, at A1.

206. Randall Kennedy, Persuasion and Distrust: A Comment on the Affirmative Action Debate, 99 HARV. L. REv. 1327, 1332 n.208 (1987).

207. Id.

208. Id.

209. R. Richard Banks, Affirmative Action-The Black's "Burden," S.F. CHRoN., July 26, 1990, at A19.

210. Id. 
those complaining about this unfortunate side-effect of affirmative action-and would probably do so vigorously. ${ }^{211}$

\section{Does Affirmative Action Benefit and Burden the Wrong Individu-} als? Many opponents of affirmative action are disturbed because it benefits some ininority group members who are unable to prove that they have been the direct victims of discrimination, and burdens some nonminorities without regard to whether they have personally been the culprits of discrimination. This argument is often framed in terms of well-off or middle-class blacks being favored over poor blacks and poor whites, and in terms of the innocent white person being purnshed while the real culprits go without punishment. 212 This perception of affirmative action seeins to haunt Justice Kennedy, as reflected in his Metro Broadcasting dissent, in which he refers to the FCC pohcies as "operat[ing] to exclude the many racial and ethmic minorities that have not made the Commission's list."213 Justice Kennedy also suggested that the FCC affirmative action policies would never be accepted by those who "have never discriminated against anyone on the basis of race."214

There are numerous ways of countering the argument that affirmative action sometimes benefits and burdens the wrong individuals. ${ }^{215}$ One of the most persuasive rebuttals to this argument focuses on the historic mistreatment of black Americans. Proponents of this argument contend that the systematic denial of equal opportumity to blacks through the institution of slavery, Black Codes, and Jim Crow laws, ${ }^{216}$ continues to heap tremendous benefits on white Americans as a group while contimuing to burden black Americans as a group. In other words, just because individual whites might have a legitimate claim of having never discriminated against a black person, no white person can credibly

211. Justice Clarence Thomas, along with Professors Shelby Steele, Thomas Sowell, Walter Williams, and Stephen Carter, are among an apparent minority of blacks who are opposed to affirmative action on any grounds. See, eg., Fred Barnes, The Minority Minority: Black Conservatives and White Republicans, NEw REPUBLIC, Sept. 30, 1991, at 18 (discussing views of "black conservatives" on a variety of issues, including their opposition to affirmative action).

212. See MAGuire, supra note 31, at 33.

213. Metro Broadcasting, 110 S. Ct. at 3045 (1990) (Kennedy, J., dissenting).

214. Id. at 3047 (quotation onnitted).

215. Maguire, for example, counters this position by arguing that "[e]quality and individualized accounting are not intrinsic to social and distributive justice." MaGUIRE, supra note 31, at 174. Maguire suggests that "[g]roup problems cannot be addressed by an analysis of all of the problems of all of the individuals in the group." Id.

216. See id. at 131-33. Adopted shortly after the Civil War, the Black Codes were a code of laws enacted by southern states to linnit the rights of recently emancipated slaves. 2 THE NEW ENCYCLOPEDIA BRITANNICA 253 (15th ed. 1989) ("[T]hough varying from state to state, [the black codes] were all intended to secure a steady supply of cheap labour, and all continued to assume the inferiority of the freed slave."). 
claim to have never benefited from the legal, systematic, and institutionalized discrimination that has been perpetuated against blacks throughout this country's history. Along these same lines, no amount of wealth or status can completely shield black Americans from the contemporary racist stereotypes and reaction to blacks born out of their long history of subordination and exploitation.

White perceptions of blacks as revealed in the National Opimion Survey discussed im the introduction provide evidence that many whites still view blacks as inferior beings. ${ }^{217}$ These perceptions undoubtedly translate imto day-to-day decisions that affect the ability of blacks to obtain jobs, promotions, and other opportunities to advance and compete fairly in society, and contribute to the racial mequality that exists in the United States. ${ }^{218}$

\section{The Status Quo and the Future of Government AFFiRMative ACTION}

The Supreme Court's two most recent government affirmative action decisions, City of Richmond v. J.A. Croson Co. ${ }^{219}$ and Metro Broadcasting, Inc. v. FCC, ${ }^{220}$ established the current constitutional framework for analyzing government affirmative action. ${ }^{221}$ In Croson, the Court ruled that strict scrutiny review should be apphied to all race-conscious classifications enacted by state and local governments. 222 This decision was celebrated by conservatives and opponents of affirmative action because the extreme difficulty of satisfying strict scrutiny review created a major liurdle to state and local government efforts to enact affirmative action policies. 223 In Metro Broadcasting, the Court surprisingly interpreted Fullilove to mean that Congress had wider latitude than state and local governments to enact affirmative action policies, thus warranting

217. See supra text accompanying notes 10-13.

218. See supra notes 5-9 and accompanying text.

219. 488 U.S. 469 (1989).

220. 110 S. Ct. 2997 (1990).

221. See Steven A. Holmes, Affirmative Action Plans Are Now Part of the Normal Corporate Way of Life, N.Y. Trmes, Nov. 22, 1991, at A11 ("Labor Department officials say more than 95,000 companies employing 27 million workers and having contracts worth a total of $\$ 184$ billion are covered by the Federal [affirmative action] program.").

222. See Croson, 488 U.S. at 493-98.

223. See Marcia Coyle \& Marianne Lavelle, Reagan Legacy Is Alive and Well at High Court, NAT'L L.J., Feb. 6, 1989, at 5 ("The decision [in Croson] was a clear victory for the former Reagan Department of Justice, which had long fought the use of quotas and other numerical remedial measures."); see also Kerry Weighing Options To Enable State, Local Set-Aside Programs to Pass Croson Test, 54 Fed. Cont. Rep. (BNA) No. 6, at 179 (1990) ("In the wake of Croson, some state and local governments have voluntarily. suspended their set-aside programs; other jurisdictions have had their programs thrown out by the courts."). 
the application of the more lenient intermediate scrutiny test to congressionally enacted affirmative action pohicies. ${ }^{224}$ Metro Broadcasting thus gave the civil rights community and proponents of affirmative action reason to celebrate because it upheld the legality and the continued use of federal affirmative action policies. ${ }^{225}$

But just when it appeared that the law of government affirmative action was settled, Justice Marshall issued a warning that Metro Broadcasting was in jeopardy of being overturned by the current majority of the Court. In Payne v. Tennessee, ${ }^{226}$ his last dissenting opinion as a meinber of the Supreine Court, Justice Marshall cautioned that the conservative makeup of the Court placed the future of congressionally mandated affirmative action $\mathrm{m}$ serious jeopardy of being limited in a manner inconsistent with the Court's decision in Metro Broadcasting. Specifically, Justice Marshall described Metro Broadcasting as an "endangered precedent" in the line of fire to be overturned by the Payne majority's "radical new exception to the doctrime of stare decisis."227 Clearly outraged by the Court's decision in Payne, Justice Marshall criticized the Payne majority for thinking and voting as though they were "free to discard any primciple of constitutional liberty which was recognized or reaffirmed over the dissenting votes of four Justices and which five or more Justices now disagree."228

224. See Metro Broadcasting, $110 \mathrm{~S}$. Ct. at 3008.

225. See David G. Savage, Court OK's Affirmative Action at Federal Level, L.A. TiMES, June 28, 1990 , at A1 ("This open-ended endorsement of minority preference policies by the federal government comes just a year after an increasingly conservative Supreme Court appeared to ban government affirmative action."). Savage also pointed out that Metro Broadcasting was a "major victory" for Democrats in Congress and for the civil rights community, and a "surprising defeat" for the Bush administration. See id.

226. 111 S.Ct. 2597 (1991). In Payne, a 6-3 majority of the Court allowed the introduction of victim-impact evidence into the sentencing phase of a capital trial, explicitly overturning two Supreme Court eases decided only a few years earlier. See id. at 2611. Chief Justice Rehnquist dehivered the opinion of the Court. Id. at 2601. Voting with the Chief Justice were Justices O'Connor, Scalia, Kennedy, and Souter. Justice Marshall wrote a dissenting opinion, jomed by Justice Blackmun. Id. at 2619. Justice Stevens wrote a dissenting opinion, joined by Justice Blackmun. Id. at 2625.

227. Id. at 2619 (Marshall, J., dissenting).

228. Id. In explaining his dissent in Payne, Justice Marshall argued that:

Power, not reason, is the new currency of this Court's decisionmaking. Four Terms ago, a five-Justice majority of this Court held that 'victim impact' evidence of the type at issue in this case could not constitutionally be introduced during the penalty phase of a capital trial. By another 5-4 vote, a najority of this Court rebuffed an attack upon this ruling just two Terms ago. Nevertheless, having expressly invited respondent to renew the attack, today's majority overrules Booth and Gathers and credits the dissenting views expressed in those cases. Neither the law nor the facts supporting Booth and Gathers underwent any change in the last four years. Only the personnel of this Court did.

Id. (citations omitted). 
For two obvious reasons, Justice Marshall's concern that the six members of the Court that comprised the majority in Payne will overturn Metro Broadcasting should be taken seriously. First, Metro Broadcasting reaffirmed the right of Congress to enact affirmative action measures over the dissenting votes of the Chief Justice and three other Justices (Scalia, Kennedy, and O'Connor), who strongly criticized the Court's decision. 229 Second, simce Metro Broadcasting was decided, two of the more liberal Justices on the Court who voted with the majority to uphold the FCC policies, Justices Brennan and Marshall, have retired and have been replaced by conservatives. ${ }^{230}$ Justice Brennan, who authored the Metro Broadcasting opinion, retired from the Court after its 1989 Term and was replaced by conservative Justice David Souter, who voted with the majority in Payne. ${ }^{231}$ Justice Marshall retired from the Court after its 1990 Term and was replaced by Justice Clarence Thomas. ${ }^{232}$ There is strong reason to beheve that both Justices Souter and Thomas will vote against affirmative action if presented with the opportunity to do so. ${ }^{233}$ In fact, both Justices have expressed opposition to affirmative action in public speeches and writings.

While serving as New Hampshire's attorney general in 1976, Justice Souter delivered a speech im which he expressed opposition to federal affirmative action, suggesting that the federal government is wrong to use

229. It is not surprising that three of the Justices who dissented in Metro Broadcasting (Justices O'Connor, Scalia, and Kennedy) were appointed by President Ronald Reagan, who is strongly opposed to affirmative action. See 2 AlmaNac of THE FEDERAL Judiciary (Stephen Nelson et al. eds., 1991); Ethan Bronner, High Court's Split on Affirmative Action Echoes Nation's Division, BosTON GLOBE, June 29, 1990, at 1.

230. All of the Justices who dissented in Metro Broadcasting remain on the Court.

231. See Ethan Bronner \& John Milne, Souter Calls Himself a 'Moderate Conservative, Boston GLOBE, Oct. 5, 1990, at 1.

232. See Sam Fulwood III \& Douglas Jehl, Thomas Takes Oath as Justice of High Court, L.A. TIMES, Oct. 19, 1991, at A.1.

233. Many believe that it is unlikely that President Bush, who is generally considered by civil rights groups to be opposed to government affirmative action, would have appointed either Justices Souter or Thomas to the Supreme Court if he did not think that they would vote consistently with his views on affirmative action. But even here, the issue is more complex. For example, President Bush, in response to a White House Counsel policy statement interpreting the 1991 Civil Rights Act as requirimg all federal agencies to termmate their longstanding practice of hiring and promoting based on affirmative action practices, denounced the statement as an inaccurate interpretation of the law and expressed his support for affirmative action. Many within the press and the civil rights commumity, however, view Bnsh's pronouncement favoring affirmative action as inconsistent with his previous actions and declarations and as political inaneuvering to counter criticism for the leaked White House policy statement. See Steven A. Holmes, Bush to Order End of Rules Allowing RaceBased Hiring, WASH. POST, Nov. 21, 1991, at A1 (reporting on leaked White House Counsel memo); Andrew Rosenthal, President Tries to Quell Furor on Interpreting Scope of New Law, WASH. Post, Nov. 22, 1991, at A1, A11 (In a speech during the White House ceremony where Bush signed the 1991 Civil Rights Act into law, he declared, "This Administration is committed to action that is truly affirmative. ... I say again today that I support affirmative action."). 
such policies. ${ }^{234}$ Specifically, he referred to federal hiring practices that consider race and ethnicity as not really lielping those minorities in need, and as "affirmative discrimination."235

Justice Thomas, who jomed the Court early in its 1991 Term, is a well-known opponent of affirmative action. He lias harshly criticized affirmative action in his writings and speeches and provided no indication during his confirmation hearings that his view of affirmative action liad changed. Justice Thomas does not believe that the government owes anything to blacks and other minorities as a result of the country's history of discriminating against minorities. ${ }^{236}$ Moreover, he believes that affirmative action saps the will and determination of blacks and other minorities to achieve, and amounts to reverse discrimination. ${ }^{237}$ Consider his 1987 letter to the editor in the Wall Street Journal:

I firmly believe that the Constitution be interpreted in a colorblind fashion. It is futile to talk of a colorblind society unless this constitutional principle is first established. Hence, I emphasize black self-help, as opposed to racial quotas and other race-conscious legal devices that only further and deepen the original problem. ${ }^{238}$

Justice Thomas's views on affirmative action are also reflected in the last opinion lie wrote before joining the Supreme Court. As a judge on the District of Columbia Circuit, Justice Thomas authored the inajority opinion in Lamprecht v. FCC, ${ }^{239}$ a case that overturned the FCC's decision to award a broadcast license to a woinan broadcaster under the coininission's gender preference policy. ${ }^{240}$ In Lamprecht, Justice Thomas distinguished the gender-preference policies at issue froin the minority-

234. See Jerry Seper, Souter's Record Under Microscope as Hearings Near, WASH. TIMES, July 26, 1990, at A3.

235. Id.; see also Tony Mauro, Souter Opinions Don't Stand Out, GANNETT NEWS SERV., July 25, 1990, available in LEXIS, Nexis Library, Wires File. As a judge on the New Hampshire Supreme Court and the First Circuit, Justice Souter was never presented with an opportunity to decide an affirmative action case. See Dawn M. Weyrich, Souter Surprise Selection for Court; Abortion Position Unknown, WASH. TIMES, July 24, 1990, at A1.

236. See Juan Williams, $A$ Question of Fairness, ATLANTIC, Feb. 1987, at 70, 79.

237. See id.

238. 'I Emphasize Black Self-Help'; Thomas's Thoughts on Quotas, the Work Ethic and Conservatism, WASH. PosT, July 2, 1991, at A7 (excerpting statements made by Justice Thomas from various publications and speeches); see also Clarence Thomas, Toward a "Plain Reading" of the Constitution-The Declaration of Independence in Constitutional Interpretation, 30 How. L.J. 983, 995 (1987) (expounding on his view that the Constitution should be interpreted in a color-blind fashion and arguing that "[t] he first principles of equality and liberty should inspire our political and constitutional thinking . . . [and] could lead us above petty squabbling over 'quotas,' 'affirmative action,' and race-conscious remedies for social ills.").

239. No. 88-1395, 1992 U.S. App. LEXIS 1997 (D.C. Cir. Feb. 19, 1992).

240. Id. This is the only affirmative action case that Justice Thomas participated in while serving as a court of appeals judge. There was some controversy about whether Justice Thomas deliberately delayed releasing the opinion to prevent members of the Senate Judiciary Committee from questioning him about the opinion during his confirmation process. See Garry Sturgess, Senate 
preference pohicies at issue in Metro Broadcasting. ${ }^{241}$ In distinguishing the two cases, Justice Thomas declared that, unlike the empirical evidence presented documenting that imcreasing the number of minority .broadcasters would lead to more diverse programming, there was no such empirical evidence presented in Lamprecht regarding women broadcasters. ${ }^{242}$ Justice Thomas stated: "The Commission's brief cites nothing that might support its predictive judgment that woinen owners will broadcast women's or minority or any other underrepresented type of programming at any different rate than will men."243 Justice Thoinas's holding in Lamprecht was strongly criticized by Judge Abner Mikva, who dissented from the holding. ${ }^{244}$

During his confirmation hearings, Justice Thomas was specifically asked about his view of Metro Broadcasting; he stated that he "had no reason to disagree" with the decision, but avoided directly coinmenting on the case. ${ }^{245}$ Although Justice Thomas's decision in Lamprecht and his remarks about Metro Broadcasting do not establish that he is against affirmative action, they do not provide any indication to the contrary.

Not only does it appear that government efforts to mandate affirmative action are in jeopardy of being severely curtailed by the Supreme Court, attacks on affirmative action are also on the rise by pohiticians, government officials, and academicians. ${ }^{246}$ Democratic politicians, for

Mulls Thomas' Controversial Case; Draft Opinion Would Overturn FCC Ruling on Gender Preferences, LEGAL TIMES, Sept. 30, 1991, at 1.

241. See Lamprecht, 1992 U.S. App. LEXIS 1997, at "11 n.1.

242. See id. at * 24-41; see also 'Promoting Diversity for Diversity's Sake, 'LEGAL. T1MEs, July 15, 1991, at 10. The FCC argued that Metro Broadcasting controlled the issue presented in Lamprecht. The following are portions of statements made by then-Judge Thomas to FCC lawyer C. Grey Pash during oral argument in the Lamprecht case on January 25, 1991:

I am left in a quandary or at least at a point where it seeins as though we are promoting diversity for diversity's sake, without an explanation as to what effect it will have on the operation of the stations. At least in the case of minorities, there was documented evidence that there was a difference in programming. ... I understand that women are a significant group, and $I$ understand that they are significant in size. But what difference does it make, if a woman owns a station? Does it make a difference in programining, does it make a difference in content of the points of view, does it inake a difference in the editorials? What difference does it make?

Id. at 11.

243. Lamprecht, 1992 U.S. App. LEXIS 1997, at *41.

244. See Lamprecht, 1992 U.S. App. LEXIS 1997, at "57. In his dissent, Judge Mikva stated: [I]t strikes me as impossible to reconcile the Supreme Court's decision in Metro Broadcasting with my colleagues' decision today. The Supreme Court held that Congress may require the FCC to make certain broadcasting licenses available only to minorities; yet this Court reaches the surprising conclusion that Congress may not require the FCC to adopt a far milder and far less discrimimatory preference program for women.

Id. at $* 58$.

245. See Sturgess, supra note 240 , at 22.

246. See supra note 16. A small but significant number of black scholars and policymakers have spoken out against affirmative action. See supra note 211; see also Bill Turque \& Bob Cohn, Black Conservatives Quarrel over Quotas, NEwsweEk, Dec. 24, 1990, at 20 ("While black conservatives 
example, are struggling to find ways to defend affirmative action after coming under increasing attack in recent years from Republicans, who argue tliat affirmative action doesn't really help minorities and amounts to reverse discrimination against whites. ${ }^{247}$ According to one writer, the Democratic Party leadership is considering ways to continue their support for affirmative action "witlout alienating key groups of white voters."248

On the academic front, the most recent assault against affirmative action-embraced by both conservative academicians and politicians-is the criticism against wliat lias been terined the "politically correct"249 movement on college and university campuses in support of admissions and other school policies favoring minorities. ${ }^{250}$ The so-called "politically correct" movement has been attacked by President Busli as an attempt to force on the American public a leftist's socio-pohtical worldview and agenda. ${ }^{251}$ Altliougli not a legal argument, the linking of affirmative action to "political correctness" has gained a lot of recognition and momentun and probably influences the way the general public, lawyers, and judges view the issue.

Despite the controversy surrounding the legitmiacy and appropriateness of affirmative action, evidence reveals overwhelming support for

don't speak with one voice on the issue, they generally oppose racial preferences for the same reasons white conservatives do."); W. John Moore, After the March, 22 NAT'L J. 1525, 1529 (1990) ("For a variety of reasons a few black activists and scholars have raised doubts about the efficacy of affirmative action programs. These critics say there is a downside psychologically and politically.").

247. The political problem with defending affirmative action is so troubling for the Democrats that some of the strongest supporters of affirmative action are suggesting that Democrats distance themselves from the policy. See Don Wyclif, Blacks Debate the Cost of Affirmative Action, N.Y. TIMEs, June 10, 1990, §4, at 3 (Stating the view of heral sociologist William Julius Wilson, Wycliff writes that "he says, such policies have alienated some whites from the Democratic Party and become an obstacle to the pohitical coalitions needed to enact 'race-neutral' social programs-job training, educational aid and so forth-that would benefit all low-income people.").

248. See Robert Shogan, Democrats See Quotas Potentially Explosive, L.A. TimEs, Dec. 23, 1990, at A4.

249. "Political correctness" has been defined in a number of ways. See, e.g., Michael Kilian, Warning on Political Correctness: Endowment Head Sees Liberal McCarthyism on Campuses, CHI. TRIB., July 31, 1991, at 4 ("The term 'pohitical correetness' is used-especially by conservatives-to refer to a liberal orthodoxy that includes support for affirmative action programs, outlawing hate speech and downplaying European and male influence on Western Civilization."); ArLynn L. Presser, The Politically Correct Law School: Where It's Right to Be Left, A.B.A. J., Sept. 1991, at 52 (Political correctness "is defined by Webster's dictionary as 'marked by or adhering to a typically progressive orthodoxy on issues involving especially race, gender, sexual affinity or ecology.' ").

250. See generally Dinesh D'Souza, Illiberal Education: The Politics of Race and Sex on Campus (1991).

251. See Alexander Cockburn, Bush Finds a Stand-In for Willie Horton: The Right, Floundering for Issues, Makes Campus 'Political Correctness' Its New Bogeyman, L.A. TIMES, May 9, 1991, at B7 (reporting that on a visit to the University of Michigan to give a commencement address, President Bush attacked "the notion of political correctness"). 
affirmative action by blacks and other minorities.252 Black America's perception of affirmative action is supported by data that shows that blacks have significantly benefited from affirmative action. ${ }^{253}$ As Professor Randall Kemiedy points out, affirmative action has "strikingly benefited blacks as a group and the nation as a whole" by enabling "blacks to attain occupational and educational advancement in nuinbers and at a pacc that would otherwise have been impossible."254 Professor Kennedy behieves that the success of affirmative action has "self perpetuating benefits" such as the "expansion of a professional class able to pass its material advantages and elevated aspirations to subsequent generations." 255

\section{CONCLUSION}

Given the social, economic, and political inequality that exists in the United States, and the evidence of continued racism and discrimination in our society, the controversy over affirmative action as a remedy for these problems is unlikely to end anytime soon, regardless of how the Supreme Court or the government responds to the issue. The primary goal of this Note is not to promote affirmative action, but to provide a basic explanation of what affirmative action is, how it came into existence, and how the question of its legality and appropriateness should be determined. In other words, any serious atteinpt to understand affirmative action should include careful consideration of the political, social, and economic factors that led to its existence; its origin and development in this country; and the constitutional principles that govern its legality. This Note is not meant to provide a comprehensive discussion or analysis of affirmative action. Instead, it attempts to provide a frainework for

252. See supra notes 204-205 and accompanying text.

253. Some of the most noticeable gams of affirmative action have been reported in the business sector:

Affirmative action has produced major gains for black job-seekers. The percentage of blacks in the work force has risen by $50 \%$ in the past 25 years-a solid advance even taking into account a larger population. ... In 1989, about $5 \%$ of all inanagers in the U.S. were black. That's a fivefold increase since 1966 and a $30 \%$ increase since 1978.

Howard Gleckman et al., Race in the Workplace, Bus. Wx., July 8, 1991, at 50.

The effect of affirmative action can be secn even beyond the business sector. As one writer noted, "[a]ffirmative action, enforced with quotas or not, has helped give hundreds of thousands of blacks access to colleges, graduate schools, jobs and promotions they inight not have achieved otherwise." Mark Whitaker, $A$ Crises of Shattered Dreams, Newsweek, May 6, 1991, at 28, 30-31.

254. Kennedy, supra note 206 , at 1328 . Professor Kennedy argues that the diversification of police forces as a result of affirmative action is a benefit to society because integrated police forces help the police better respond to and understand crime in minority communities, thus improving public safety. See id.

255. Id. As one writer notes, affirmative action programs are "so pervasive in the American workplace that a Reagan Administration attempt in 1985 to curtail them was opposed by corporate lobbyists as well as civil rights groups." Holmes, supra note 221, at A11. 
understanding affirmative action, and for developing a position on whether it is a policy that should be employed by our government and other institutions in our society. 
